Supplement of Geosci. Model Dev., 9, 4313-4338, 2016

http://www.geosci-model-dev.net/9/4313/2016/

doi:10.5194/gmd-9-4313-2016-supplement

(c) Author(s) 2016. CC Attribution 3.0 License.

(c) (i)

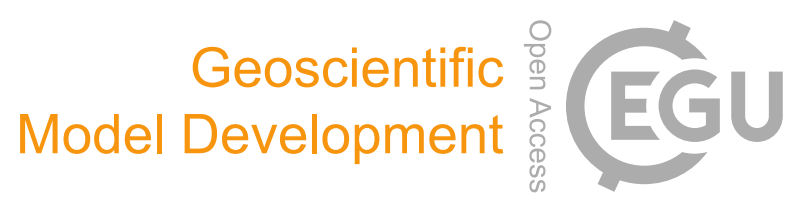

Supplement of

\title{
Parameter interactions and sensitivity analysis for modelling carbon heat and water fluxes in a natural peatland, using CoupModel v5
}

Christine Metzger et al.

Correspondence to: Christine Metzger (cmetzger@kth.se)

The copyright of individual parts of the supplement might differ from the CC-BY 3.0 licence. 


\section{$1 \quad 1$ Supplementary model description}

2 Vascular plants consisted of three functional parts: roots, photosynthetically active biomass

3 (i.e. green leaves and green stems that are labelled as leaves in equations and parameter

4 names), and photosynthetically passive biomass (i.e. brown, senescent leaves and woody

5 stems that are labelled as stems). Mosses were considered to consist of two parts: an upper,

6 photosynthetically active part (labelled as leaves) and a lower, photosynthetically passive part

7 (labelled as roots) representing pale or brown, belowground leaves and stems that are still

8 living. Each plant constitutes a biomass pool for each of its parts.

9 Plant development started every spring when the accumulated sum of air temperatures above

10 a threshold value reached a certain value. The accumulation of temperatures started when the

11 day length (geometric estimated time of sun above horizon) exceeded 10 hours. Snow cover

12 hindered leafing-out by reducing the radiation supply to the plant, while low soil temperatures

13 reduced plant water uptake.

14 Senescence and litter fall differed between the two plant types. For vascular plants, beside a

15 small amount of litter fall occurring during the whole plant growth period (cf. Fulkerson and

16 Donaghy, 2001), senescence was assumed to start after the plant reached maturity and

17 therefore depended on growth stage (cf. Thomas and Stoddart, 1980) and dormancy

18 temperatures (cf. Davidson and Campbell, 1983). New assimilates were constantly allocated

19 to the roots and to the photosynthetically active part. After maturity, existing green biomass

20 was reallocated to the photosynthetically passive part. A third stage of litter fall was

21 configured depending on a temperature threshold: Five consecutive days in the autumn with

22 day lengths shorter than 10 hours and with temperatures below a threshold temperature

23 parameter terminated the growing season; Increased litter fall took place and vascular plants

24 went to dormancy. During vascular plant litter fall, part of the carbon was stored in the mobile

25 pool, which could be then reused for leafing-out in the next year (cf. White, 1973; Wingler,

26 2005). The litter from above ground biomass was inserted to a surface litter pool, while root

27 litter was inserted to the corresponding litter pools of the soil layers in which the roots were

28 located. The litter in the surface pool was inactive and transferred with a constant rate to the

29 litter pool of the uppermost layer.

30 A different approach for senescence and litter fall was applied for mosses, as they largely

31 differ in these processes from vascular plants: Sphagnum mosses produce new leaves in the 
1 top (capitula), while litter fall occurs on the lower leaves, when they become shaded and die

2 (cf. Clymo and Hayward, 1982). This leads to a permanent moss cover and a litter fall that is

3 proportional to assimilation. In the model, this was realised by keeping the photosynthetically

4 active part of mosses to a fixed static value. Any losses (i.e. respiration and litter fall) or gains

5 (incorporation of assimilates) were restricted to the belowground moss parts. Therefore a

6 higher range for the parameter scaling growth respiration of mosses was calibrated (cf. Table

7 S1). Moss litter was produced with a constant rate coefficient throughout the year and was

8 directly inserted to the corresponding soil litter pools. The dormancy period for mosses was

9 initiated in the same way as for vascular plants, but affected only assimilation.

10

\section{Supplementary tables}

12 Table S1. Calibrated parameters

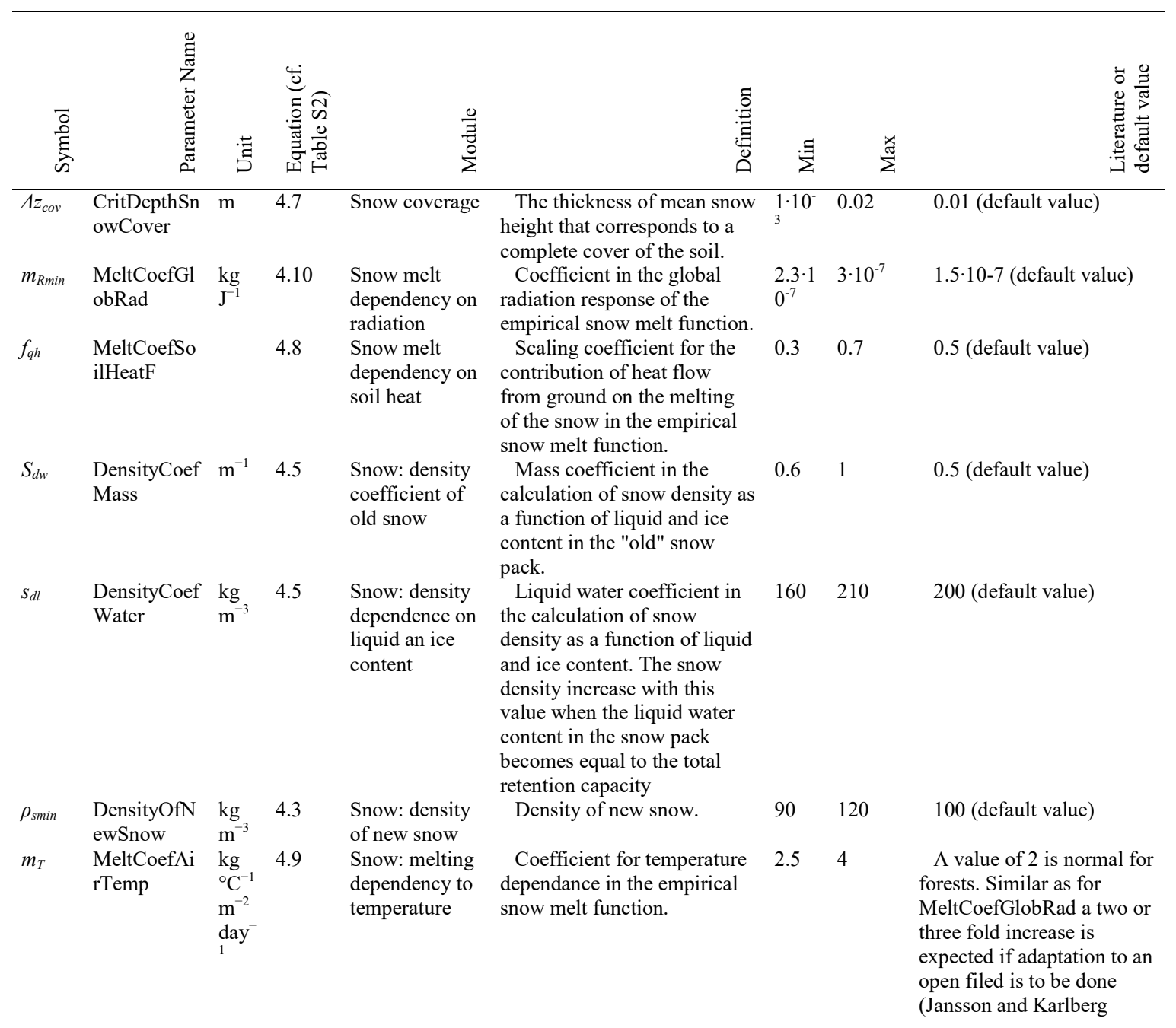




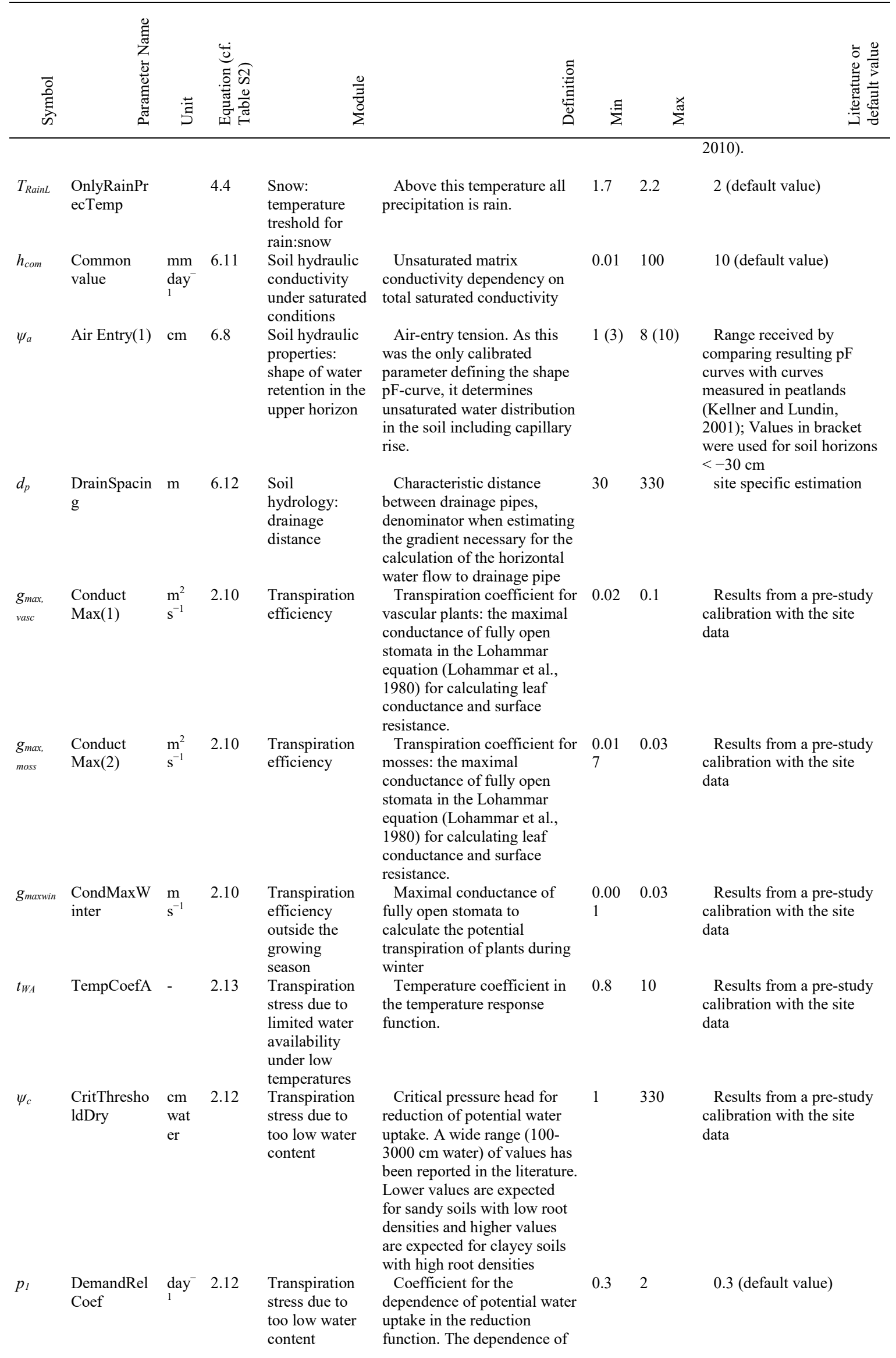




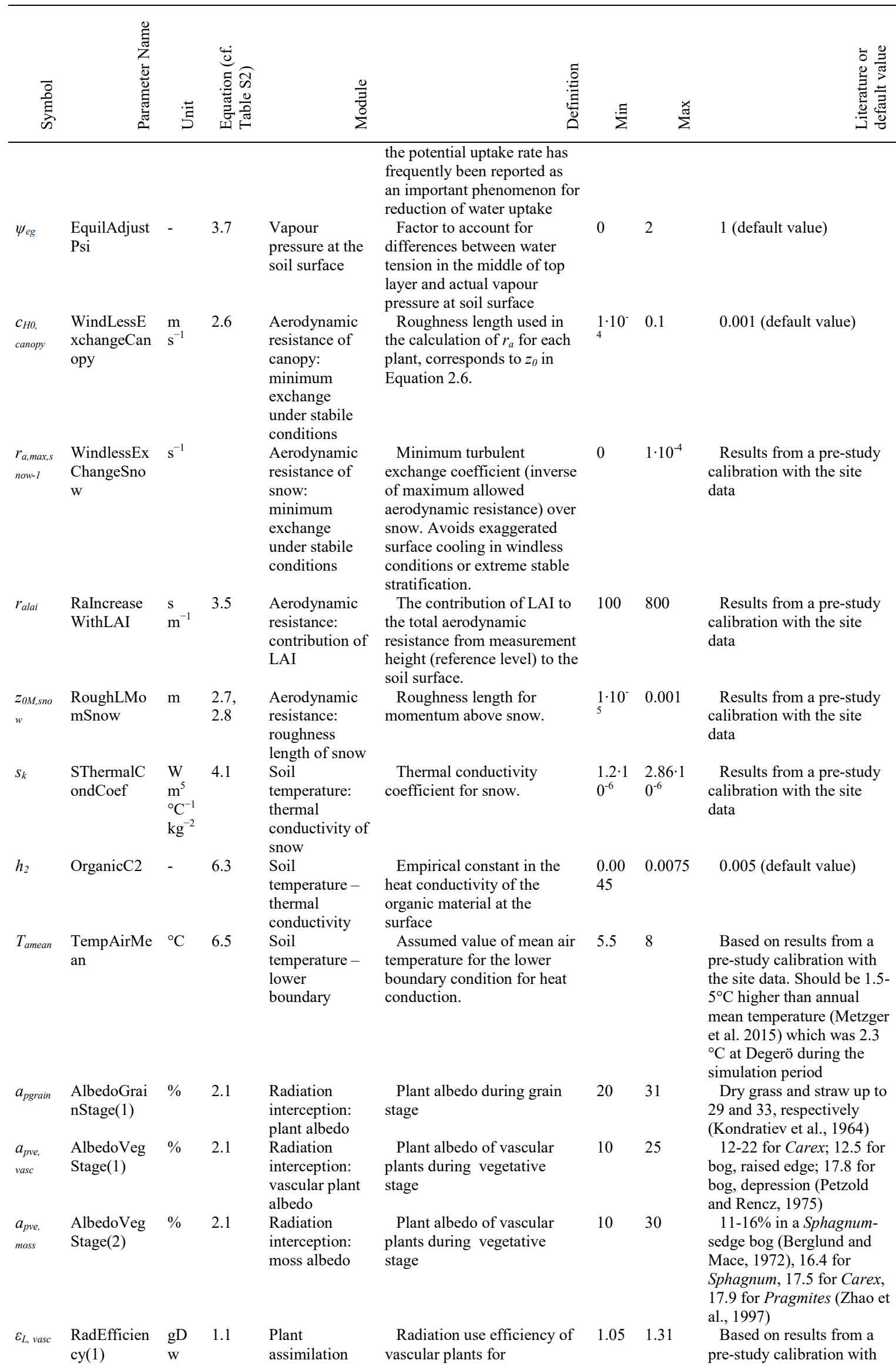




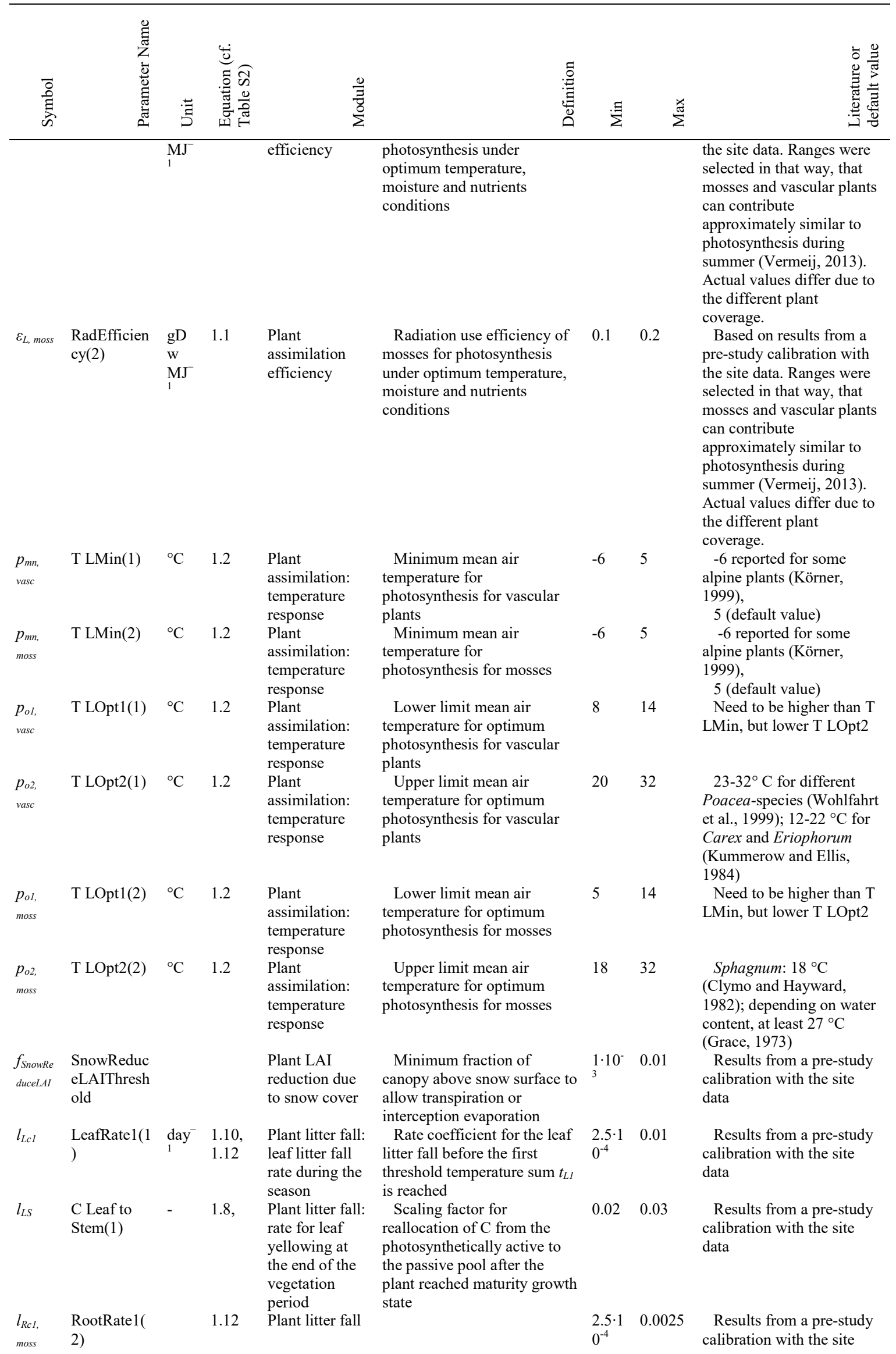




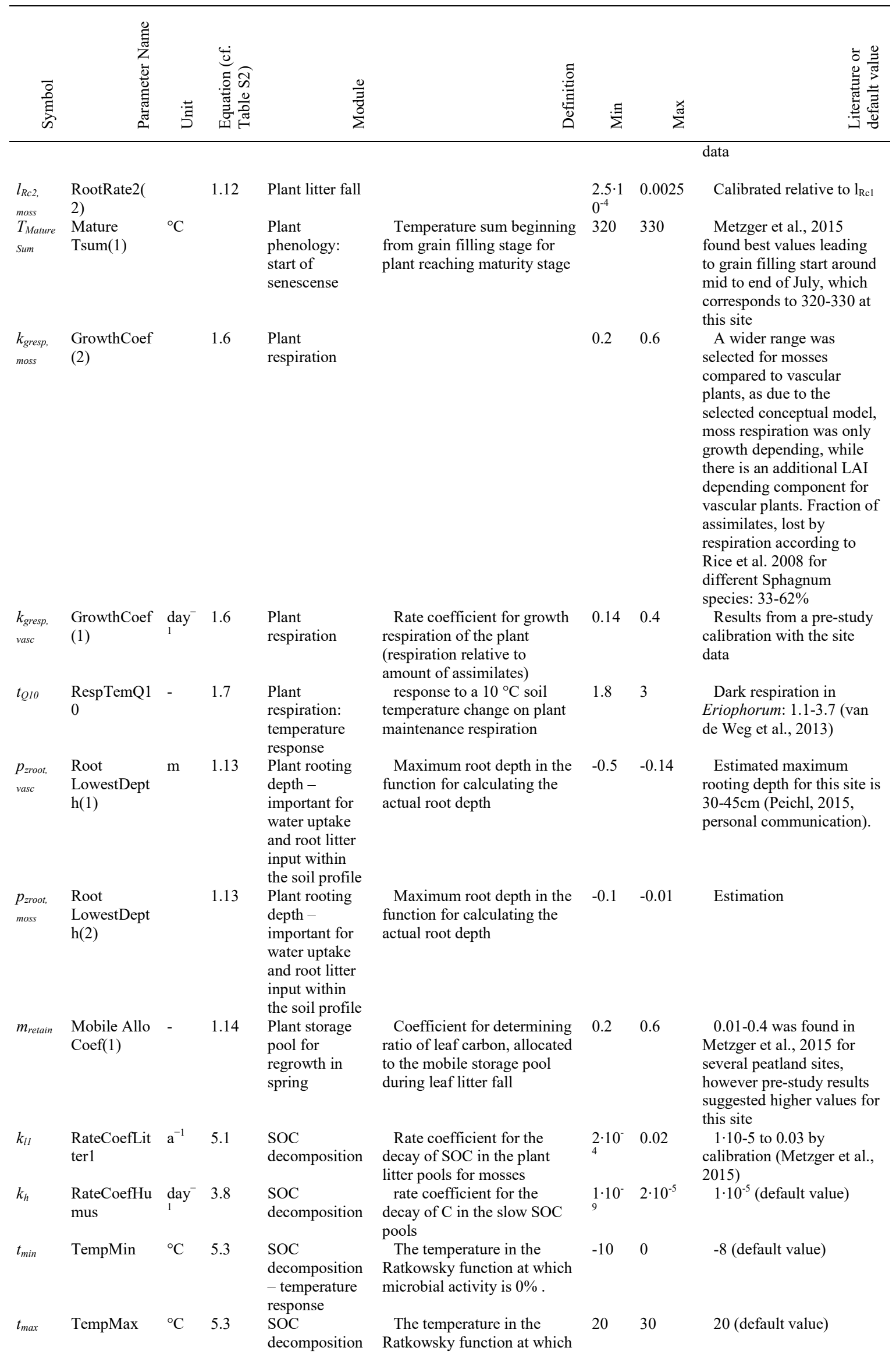




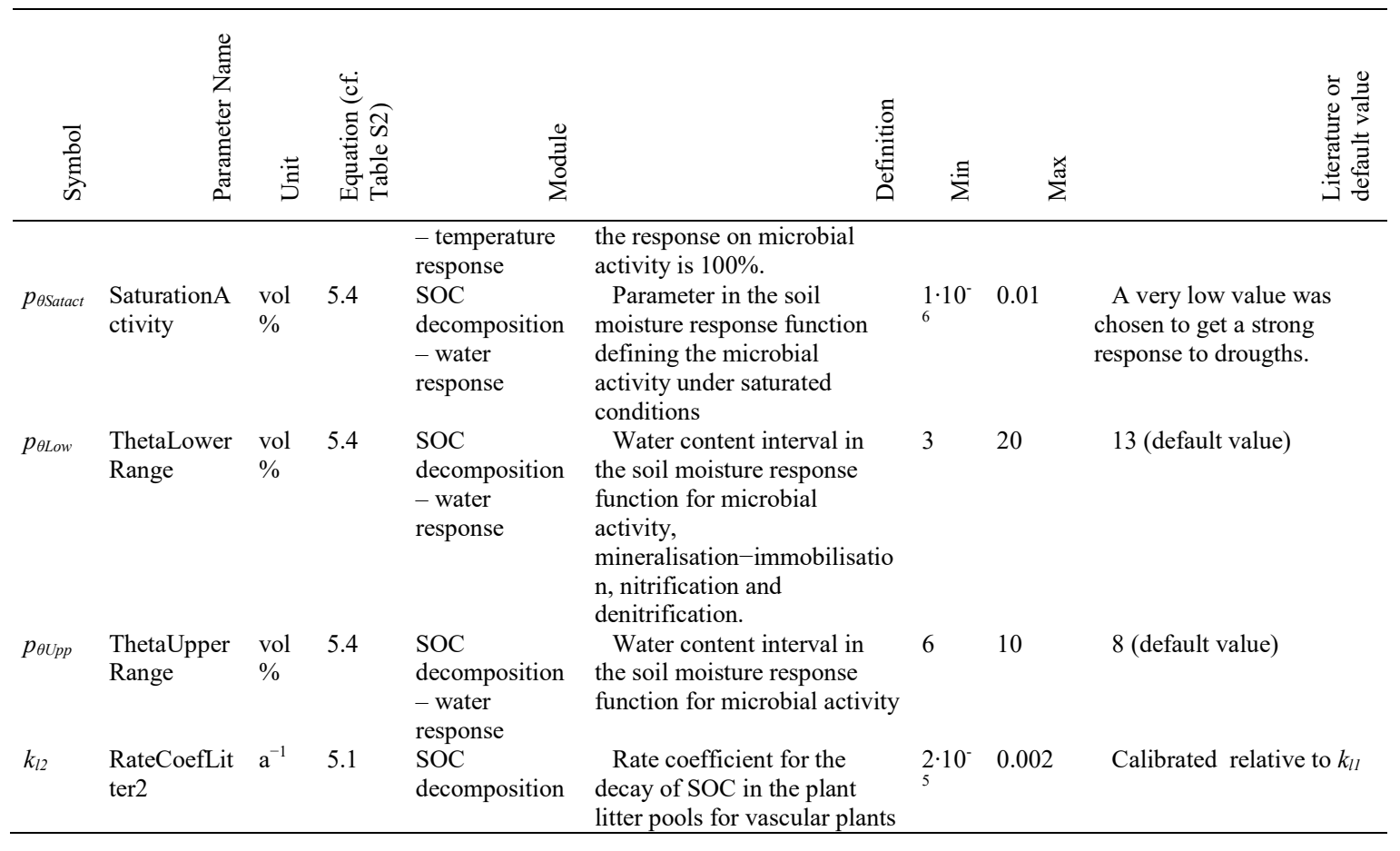




\section{Table S2. List of main equations used in this study}

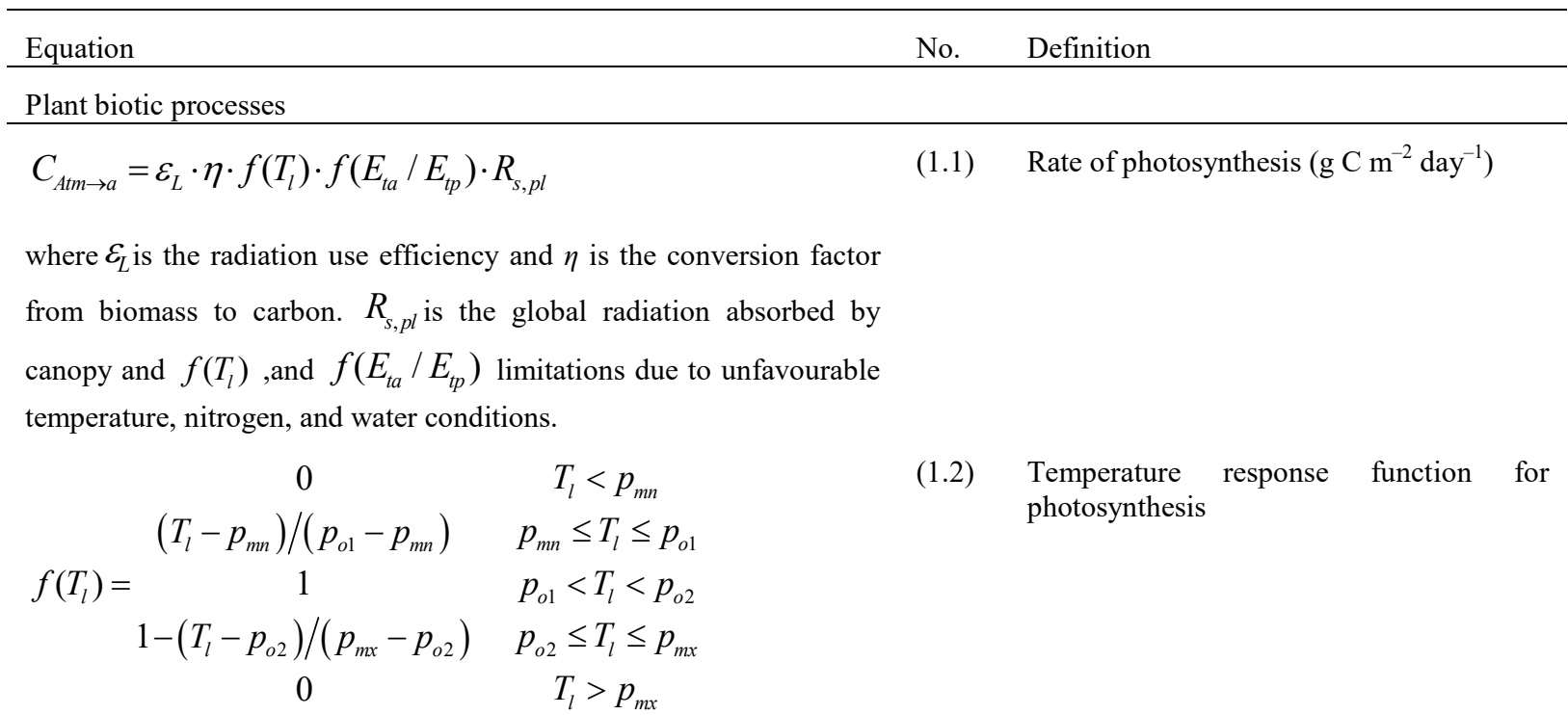

where $p_{m n}, p_{o 1}, p_{o 2}$ and $p_{m x}$ are parameters and $T_{l}$ the leaf temperature.

$$
f\left(E_{t a} / E_{t p}\right)=\frac{E_{t a}}{E_{t p}}
$$

Response function for transpiration

where $E_{t a}$ (Eq. 29) and $E_{t p}$ (Eq. 23) are actual and potential transpiration.

$$
C_{a \rightarrow \text { Leaf }}=l_{c l} \cdot C_{a}
$$

where $l_{c}$, is a parameter and $C_{a}$ the new assimilated carbon.

$$
C_{a \rightarrow \text { Root }}=\left(1-l_{c l}\right) \cdot C_{a}
$$

where $l_{c}$, is a parameter and $C_{a}$ the new assimilated carbon.

$$
C_{\text {respleaf }}=k_{\text {mrespleaf }} \cdot f(T) \cdot C_{\text {leaf }}+k_{\text {gresp }} \cdot C_{a \rightarrow \text { Leaf }}
$$

where $k_{\text {mrespleaf }}$ is the maintenance respiration coefficient for leaves, $k_{\text {gresp }}$ is the growth respiration coefficient, and $f\left(T_{a}\right)$ is the temperature. The equation calculates respiration from stem, roots, and grains by exchanging $k_{\text {mrespleaf }}$ to $k_{\text {mrespstem }}, k_{\text {mresproot }}, k_{\text {mrespgrain }}$, and using the corresponding storage pools. Respiration from the old carbon pools is estimated with the same maintenance respiration coefficients as for respiration from new carbon pools.

$$
f(T)=t_{Q 10}{ }^{\left(T-t_{Q 10 b a s}\right) / 10}
$$

where $\mathrm{t}_{\mathrm{Q} 10}$ and $\mathrm{t}_{\mathrm{Q} 10 \text { bas }}$ are parameters.

$$
C_{\text {Leaf } \rightarrow \text { Stem }}=l_{L S} \cdot C_{\text {Leaf }}
$$

where $l_{L S}$ is a parameter and $C_{\text {Leaf }}$ the carbon in the leaf pool.

$$
C_{\text {Leaf } \rightarrow \text { LitterSurface }}=f\left(T_{\text {Sum }}\right) \cdot f\left(A_{l}\right) \cdot s_{\text {newleaf }} \cdot C_{\text {Leaf }}
$$

where $S_{\text {newleaf }}$ is a scaling factor. Stem C is calculated analogously with $S_{\text {newstem. }}$.

$$
f\left(l_{L c}\right)=l_{L c 1}+\left(l_{L c 2}-l_{L c 1}\right) \cdot \min \left(1, \frac{\max \left(0, T_{S u m}-t_{L 1}\right)}{\max \left(1, t_{L 2}-t_{L 1}\right)}\right)
$$

(1.10) Leaf litter fall dependence of temperature sum

Allocation of new assimilates to the roots, respectively to below ground parts in case of mosses

Plant growth and maintenance respiration $\left(\mathrm{g} \mathrm{C} \mathrm{m}^{-2}\right.$ day $^{-1}$ )

Temperature response function for maintenance respiration $(-)$

Reallocation of C from leaf pool to stem pool - here used as pool for senescent leaves.

Leaf $\mathrm{C}$ entering the surface litter pool is depending on the temperature sum and leaf area index. 
where $t_{L 1}, t_{L 2}, l_{L c 1}$ and $l_{L c 2}$ are parameters and $T_{S u m}$ is the so called "dorming" temperature sum, $T_{\text {DormSum }} . T_{\text {DormSum }}$ is calculated at the end to the growing season when the air temperature is below the threshold temperature $T_{\text {DormTth }}$, as the accumulated difference between $T_{\text {DormTth }}$ and Ta. $T_{\text {DormTth }}$ is a parameter.

The stem litter rate is calculated analogously with the parameters $t_{S I}$, $t_{S 2}, l_{S c 1}$ and $l_{S c 2}$, the root litter rate with the parameters $l_{L c 2}$ to $t_{R 1}, t_{R 2}$, $l_{R c l}$ and $l_{R c 2}$.

$$
f\left(A_{l}\right)=e^{l_{\text {LaiEnh }} \cdot A_{l}}
$$

Litter fall dependency of LAI

where $l_{\text {LaiEnh }}$ is a parameter and $A_{l}$ the leaf area index

$$
C_{\text {Root } \rightarrow \text { Litter }}=f\left(l_{R c}\right) \cdot C_{\text {Root }} \cdot S_{\text {newroot }}
$$

(1.12) Root C entering the soil litter pool of the corresponding layer

where $s_{\text {newroot }}$ is a scaling factor. The root litter rate function, $f\left(l_{R c}\right)$, can be calculated with Eq. (10) by exchanging the parameters $t_{L 1}, t_{L 2}, l_{L c 1}$ and $l_{L c 2}$ to $t_{R l}, t_{R 2}, l_{R c 1}$ and $l_{R c 2}$.

$$
z_{r}=p_{\text {zroot }}\left(\frac{B_{r}}{B_{r}+\frac{p_{\text {zroot }}}{p_{\text {incroot }}}}\right)
$$

where $p_{\text {zroot }}$ and $p_{\text {incroot }}$ are parameters and $B_{r}$ is the mass of roots (i.e. the carbon content in the roots, $\left.C_{\text {Roots }}+C_{\text {OldRoots }}\right)$.

$C_{\text {Mobile }}=\left(C_{\text {Leaf } \rightarrow \text { LitterSurface }}+C_{\text {OldLeaf } \rightarrow \text { LitterSurface }}\right) \cdot m_{\text {retain }}$

Allocation to the mobile $\mathrm{C}$ pool for developing new leaves during litter fall

where $m_{\text {retain }}$ is an allocation coefficient.

$C_{\text {RemainLeaf }}=C_{\text {OldLeaf }}\left(1-\frac{1}{l_{\text {life }}-1}\right)$

(1.15) Fraction of the whole $C_{\text {OldLeaf }}$ pool that will be excluded from the calculation of the litterfall from the old leaves

where $l_{\text {life }}$ is a parameter

$C_{\text {Mobile } \rightarrow \text { Leaf }}=C_{\text {Mobile }} \cdot m_{\text {shoot }}$

(1.16) Allocation from the mobile $\mathrm{C}$ pool at leafing (between GSI 1 and 2) as an additional supply. This process goes on as long as there is carbon left in the mobile pool. mobile pool.

Plant abiotic processes

$$
R_{s, p l}=\left(1-e^{-k_{r n} \frac{A_{l}}{f_{c c}}}\right) \cdot f_{c c}\left(1-a_{p l}\right) R_{i s}
$$

Plant interception of global radiation $\left(\mathrm{MJ} \mathrm{m}^{-2}\right.$ day $\left.^{-1}\right)$

where $k_{r n}$ is the light use extinction coefficient given as a single parameter common for all plants, $f_{c c}$ is the surface canopy cover, $a_{p l}$ is the plant albedo and $R_{i s}$, is the global qion.

The plant albedo is calculated from the parameters: albedo vegetative stage, apveg, and/or albedo grain stage, apgrain, depending on plant development.

$f_{c c}=p_{c \max }\left(1-e^{-p_{c k} A_{l}}\right)$

Surface canopy cover $\left(\mathrm{m}^{2} \mathrm{~m}^{-2}\right)$

Where $p_{c \max }$ is a parameter that determines the maximum surface cover and $p_{c k}$ is a parameter that governs the speed at which the maximum surface cover is reached. $A_{l}$ is the leaf area index of the plant. 


$$
A_{l}=\frac{B_{l}}{p_{l, s p}}
$$

Where $p_{l, s p}$ is a parameter and $B_{l}$ is the total mass of leaf.

$$
L_{v} E_{t p}=\frac{\Delta R_{n}+\rho_{a} c_{p} \frac{\left(e_{s}-e_{a}\right)}{r_{a}}}{\Delta+\gamma\left(1+\frac{r_{s}}{r_{a}}\right)}
$$

where $R_{n}$ is net radiation available for transpiration, $e_{s}$ is the vapour pressure at saturation, $e_{a}$ is the actual vapour pressure, $\rho_{a}$ is air density, $c_{p}$ is the specific heat of air at constant pressure, $L_{v}$ is the latent heat of vaporisation, $\Delta$ is the slope of saturated vapour pressure versus temperature curve, $\gamma$ is the psychrometer 'constant', $r_{s}$ is 'effective' surface resistance and $r_{a}$ is the aerodynamic resistance.

$r_{a}^{*}=\frac{\ln ^{2}\left(\frac{z_{r e f}-d}{z_{0}}\right)}{k^{2} u}+\Delta z_{\text {snow }}$

where the wind speed, $u$, is given at the reference height, $z_{\text {ref, }} k$ is von Karman's constant, $d$ is the displacement height and $z_{o}$ is the roughness length.

$$
\begin{array}{ll}
z_{0}=z_{\text {Omax }} & z_{0}>z_{\text {Omax }} \\
z_{0}=\left(H_{p}-\Delta z_{\text {snow }} \min \left(f_{1}, f_{2}\right)\right)+\Delta z_{\text {snow }} & z_{\text {Omin }}>z_{0}>z_{\text {Omax }} \\
z_{0}=z_{\text {Omin }} & z_{0}<z_{\text {Omin }}
\end{array}
$$

where $z_{0 \max }$ and $z_{0 \min }$ are parameters, $f_{1}$ and $f_{2}$ are functions describing the dependency on leaf area index and canopy density, $\Delta z_{\text {snow }}$ is the snow depth and $H_{p}$ is the canopy height.

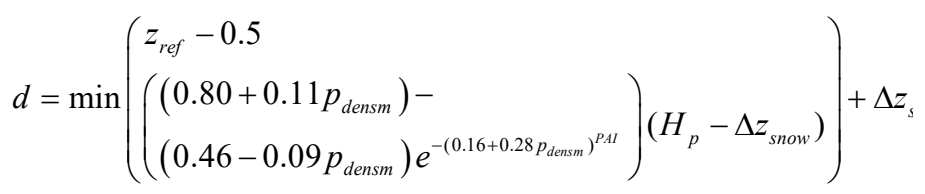

$p_{\text {densm }}$ is density maximum of canopy in relation to the canopy height, $\Delta z_{\text {snow }}$ is the snow depth. $P A I$ is the plant area index, $H_{p}$ is the canopy height.

$$
r_{s}=\frac{1}{\max \left(A_{l} g_{l}, 0.001\right)}
$$

where $g_{l}$ is the leaf conductance and $A_{l}$ the leaf area index.

$$
g_{l}=\frac{R_{i s}}{R_{i s}+g_{\text {ris }}} \frac{g_{\max }}{1+\frac{\left(e_{s}-e_{a}\right)}{g_{v p d}}}
$$

The roughness length, $z_{0}$, is calculated according to the function derived from Shaw and Pereira (1982)

Displacement height $d$, as calculated by the Shaw and Pereira function

Stomatal resistance $\left(\mathrm{s} \mathrm{m}^{-1}\right)$

Stomatal conductance per leaf area

$\left(\mathrm{m} \mathrm{s}^{-1}\right)$

(2.11) Actual transpiration without flexibility of water transportation within the root system.

where $g_{\text {ris }}, g_{\max }$ and $g_{v p d}$ are parameter values, $g_{\text {maxwin }}$ corresponds to $g_{v p d}$ in winter. $R_{i s}$, is the global radiation and $\left(e_{s}-e_{a}\right)$ the vapour pressure deficit.

$$
E_{t a}=E_{t p}^{*} \int_{z_{r}}^{0} f(\psi(z))(T(z)) r(\mathrm{z})
$$


$z_{r}$ is root depth (Eq. 16), $f(\psi(z))$ and $f(T(z))$ are response functions for soil water potential, and soil temperature and $r(z)$ is the relative root density distribution which is exponentially decreasing from soil surface to the root depth.

$$
f(\psi(z))=\left(\frac{\psi_{c}}{\psi(z)}\right)^{p_{1} E_{t p}+p_{2}}
$$

Transpiration response to water stress

where $p_{1}, p_{2}$ and $\psi_{c}$ are parameters. If the soil water potential is reaching the wilting point, $\psi_{\text {wilt }}$, the uptake is assigned to be zero from that horizon.

$$
f(T(z))=1-e^{-t_{W A} \max \left(0, T(z)-T_{\text {trig }}\right)^{T W B}}
$$

Transpiration response to temperature as proposed by Axelsson and Ågren (1976)

where $t_{W A}$ and $t_{W B}$ and the trigging temperature $T_{\text {trig }}$ are parameters.

\section{Surface Energy balance}

$$
R_{n s}=L_{v} E_{s}+H_{s}+q_{h}
$$

$H_{s}=\rho_{a} c_{p} \frac{\left(T_{s}-T_{a}\right)}{r_{a s}}$

where air density, $\rho_{a}$ and the specific heat of air at constant pressure, $c_{p}$ are considered as physical constants, $r_{a s}$ is the aerodynamic resistance calculated as a function of wind and temperature gradients

$$
r_{a s}=r_{a a}+r_{a b}
$$

where $r_{a a}$ is a function of wind speed and temperature gradients, which is corrected for atmospheric stability, and $r_{a b}$ is an additional resistance representing the influence of the crop cover,

$$
\frac{r_{a a}=\frac{1}{k^{2} u}\left\{\ln \left(\frac{z_{r e f}-d}{z_{0 M}}\right)-\psi_{\mathrm{M}}\left(\frac{z_{r e f}-d}{L_{O}}\right)+\psi_{\mathrm{M}}\left(\frac{z_{0 M}}{L_{0}}\right)\right\} \times}{\times\left\{\ln \left(\frac{z_{r e f}-d}{z_{0 H}}\right)-\psi_{\mathrm{H}}\left(\frac{z_{r e f}-d}{L_{O}}\right)+\psi_{H}\left(\frac{z_{0 H}}{L_{0}}\right)\right\}}
$$

where $u$ is the wind speed at the reference height, $z_{\text {ref }}, d$ is the zero level displacement height (c.f. potential transpiration of plant), $k$ is the von Karmans constant and $z_{O M}$ and $z_{O H}$ are the surface roughness lengths for momentum and heat respectively. If $z_{O M}$ is exchanged to $z_{0 M, \text { snow }}$ the equation can be used for snow surfaces. $L_{O}$ is the Obukhov length and $\psi_{M}$ and $\psi_{H}$ are empirical stability functions for momentum and heat respectively.
The physically based approach, for calculating soil evaporation, originates from the idea of solving an energy balance equation for the soil surface. According to the law of conservation of energy the net radiation at the soil surface, $R_{n s}$, is assumed to be equal to the sum of latent heat flux, $L_{v} E_{s}$, sensible heat flux, $H_{s}$ and heat flux to the soil, $q_{h}$. The three different heat fluxes are estimated by an iterative procedure where the soil surface temperature, $T_{s}$, is varied according to a given scheme until the equation is balanced

sensible heat flux, $H_{s}$

Aerodynamic resistance above the soil surface, $r_{a s}$, is calculated as a sum of two components

Stability function for aerodynamic resistance at neutral conditions 
Furthermore, an upper limit of the aerodynamic resistance in extreme stable conditions is set by the "windless exchange" coefficient, $r_{a, \text { soil,max }}^{-1}$

$r_{a b}=r_{a L a i} A_{l}$

where $r_{\text {alai }}$ is an empirical parameter

$$
L_{v} E_{s}=\frac{\rho_{a} c_{p}\left(e_{\text {surf }}-e_{a}\right)}{\gamma \cdot r_{a s}}
$$

Where $e_{\text {surf }}$ is the vapour pressure at the soil surface and $e_{a}$ is the actual vapour pressure in the air.

$$
e_{\text {surf }}=e_{s}\left(T_{s}\right) e^{\left(\frac{-\psi_{1} M_{\text {wate }} g \cdot e_{\text {corr }}}{R\left(T_{s}+T_{\text {absero }}\right.}\right)}
$$

where $R$ is the gas constant, $M_{\text {water }}$ is the molar mass of water, $g$ is the gravity constant and $e_{s}$ is the vapour pressure at saturation.

The empirical correction factor, $e_{\text {corr }}$, depends on an empirical parameter $\psi_{e g}$ and a calculated mass balance at the soil surface, $\delta_{\text {surf }}$, which is allowed to vary between the parameters $s_{\text {def }}$ and $s_{\text {excess }}$ given in $\mathrm{mm}$ of water.

$$
q_{h}=k_{h} \frac{\left(T_{s}-T_{1}\right)}{\frac{\Delta z_{1}}{2}}+L q_{v, s}
$$

where $k_{h}$ is the thermal conductivity of the top soil layer, $L v$, as well as the psychrometer constant, $\gamma$, are considered as physical constants; $q_{v, s}$, is the vapor flow from the soil surface to the central point of the uppermost compartment

$$
q_{v, s}=-d_{v a p d} f_{a} D_{0}(T) \frac{\left.c_{v l}-c_{v s}\right)}{\frac{\Delta z}{2}}
$$

where $d_{\text {vaph }}$ is the tortuosity given as an empirical parameter, $D_{0}$ is the diffusion coefficient for a given temperature, $f_{a}$ is the fraction of air filled pores $\left(\theta_{s}-\theta_{s}\right)$ and $c_{v s}$ and $c_{v l}$ are the concentrations of water vapour at the soil surface and at the middle of the uppermost compartment respectively.
Additional aerodynamic resistance representing the influence of the crop cover

Sum of latent heat flux, $L_{v} E_{s}$

Vapour pressure at the soil surface

Heat flux to the soil, $q_{h}$.

Vapor flow from the soil surface to the central point of the uppermost compartment

\section{Snow}

$k_{\text {snow }}=s_{k} \rho_{\text {snow }}^{2}$

Thermal conductivity of snow

where $s_{k}$ is an empirical parameter.

$\rho_{\text {snow }}=\frac{\rho_{\text {prec }} \Delta z_{\text {prec }}+\rho_{\text {old }} \Delta z_{\text {old }}}{\Delta z_{\text {snow }}}$

$\rho_{\text {prec }}=\rho_{\text {smin }}+181 \frac{\left(1-Q_{p}\right)}{f_{\text {liqmax }}}$

where $\rho_{\text {smin }}$ is the density of new snow, $Q_{p}$ is the thermal quality of precipitation and $f_{\text {liqmax }}$ is a parameter that defines the maximum liquid water content of falling snow that is automatically put to 0.5 . 


$$
Q_{P}=\left\{\begin{array}{cc}
\min \left(1,\left(1-f_{\text {liqmax }}\right)+f_{\text {liqmax }} \frac{T_{a}-T_{\text {RainL }}}{T_{\text {SnowL }}-T_{\text {Rain }}}\right) & T_{a} \leq T_{\text {Rain L }} \\
0 & T_{a}>T_{\text {RainL }}
\end{array}\right.
$$

where $f_{\text {liqmax }}$ is a parameter that defines the maximum liquid water content of falling snow and is automatically put to 0.5 . $\mathrm{T}_{\text {RainL }}$ and $\mathrm{T}_{\text {SnowL }}$ are the temperature range where precipitation is regarded as a mixture of ice and liquid water.

$\rho_{\text {old }}=\rho_{\text {smin }}+S_{d l} \frac{S_{w l}}{S_{w l m a x}}+s_{d w} S_{r e s}$

where $s_{d l}$ and $s_{d w}$ are parameters, $S_{w l \max }$ is the retention capacity and $S_{\text {res }}$ is the water equivalent of the snow.

$\Delta z_{\text {old }}=\frac{S_{\text {res }}}{\rho_{\text {old }}}$

$f_{\text {bare }}=\left\{\begin{array}{cc}\frac{\Delta z_{\text {snow }}}{\Delta z_{\text {cov }}} & \Delta z_{\text {snow }}<\Delta z_{\text {cov }} \\ 0 & \Delta z_{\text {snow }} \geq \Delta z_{\text {cov }}\end{array}\right.$

where $\Delta z_{c o v}$ is a threshold parameter.

$M=M_{T} T_{a}+M_{R} R_{i s}+\frac{f_{q h} q_{h}(0)}{L_{f}}$

where $T_{a}$ is air temperature, $R_{i s}$ is global radiation, $f_{q h}$ is a scaling coefficient and $L_{f}$ is the latent heat of freezing. Melting will affect the whole snow pack, whereas refreezing will only affect a limited surface layer.

$M_{T}=\left\{\begin{array}{cc}m_{T} & T_{a} \geq 0 \\ \frac{m_{T}}{\Delta z_{\text {snow }} m_{f}} & T_{a}<0\end{array}\right.$

where $T_{a}$ is air temperature and $m_{T}$ And $m_{f}$ are parameters.

$M_{R}=m_{R \min }\left(1+s_{1}\left(1-e^{-s_{2} s_{a g e}}\right)\right)$

where $\mathrm{mRmin}_{\mathrm{R}} s_{1}$ and $s_{2}$ are parameters.

Age of surface snow, sage, is determined by the number of days since the last snowfall. To reduce the influence of mixed precipitation and minor showers, snowfall is counted in this context only for snow spells larger than a critical value, $p_{\text {samin }}$, and for precipitation with thermal quality, $Q_{p}$, above a threshold value

Soil carbon and nitrogen processes

$C_{\text {DecompL }}=k_{l} \cdot f(T) \cdot f(\theta) \cdot C_{\text {Litter }}$

(5.1) Decomposition of the SOC pools for plant litter $\left(\mathrm{g} \mathrm{C} \mathrm{m}^{-2} \mathrm{day}^{-1}\right)$ 
Where $k_{l}$ is a parameter and $f(T)$ and $f(\theta)$ are response functions for soil temperature and moisture in the certain layer.

$$
C_{\text {DecompH }}=k_{h} \cdot f(T) \cdot f(\theta) \cdot C_{\text {Humus }}
$$

Where $k_{h}$ is a parameter and $f(T)$ and $f(\theta)$ are response functions for soil temperature and moisture in the certain layer.

$$
\begin{array}{cc}
f(\mathrm{~T})=1 & T>t_{\text {max }} \\
f(\mathrm{~T})=\left(\frac{T-t_{\text {min }}}{t_{\text {max }}-t_{\text {min }}}\right)^{2} & t_{\text {min }}<T<t_{\text {max }} \\
f(\mathrm{~T})=0 & T<t_{\text {min }}
\end{array}
$$

Where $t_{\min }$ and $t_{\max }$ are parameters and $T$ the soil temperature in the certain layer.

$$
f(\theta)=\min \left(\begin{array}{c}
\theta=\theta_{s} \\
\left(\frac{\theta_{s}-\theta}{p_{\theta U p p}}\right)^{p_{\theta p}}\left(1-p_{\theta s a t a c t}\right)+p_{\theta \text { satact }}, \\
\left(\frac{\theta-\theta_{\text {wilt }}}{p_{\theta \text { Low }}}\right)^{p_{\theta p}} \\
0
\end{array}\right) \quad \begin{gathered}
\theta_{\text {wilt }} \leq \theta \leq \theta_{s} \\
\theta<\theta_{\text {wilt }}
\end{gathered}
$$

where $p_{\theta \text { UVp }}, p_{\theta L o w}, p_{\theta \text { Satact }}$, and $p_{\theta p}$ are parameters and the variables, $\theta_{s}$, $\theta_{\text {wilt }}$, and $\theta$, are the soil moisture content at saturation, the soil moisture content at the wilting point, and the actual soil moisture content, respectively.

$C_{\text {LitterSurface } \rightarrow \text { Litterl }}=l_{l l} \cdot C_{\text {LitterSurface }}$

where $l_{l l}$ is a parameter and $C_{\text {LitterSurface }}$ the carbon in the surface litter pool.

$$
C_{\text {Litter } \rightarrow \mathrm{CO}_{2}}=\left(1-f_{e, l}\right) \cdot C_{\text {DecompL }}
$$

where $f_{e, l}$ is a parameter

$$
C_{\text {Litter } \rightarrow \text { Humus }}=f_{e, l} \cdot f_{\mathrm{h}, 1} \cdot C_{\text {DecompL }}
$$

where $f_{e, l}$ and $f_{h, l}$ are parameters

$$
C_{\text {Litter } \rightarrow \text { Litter }}=f_{e, l}\left(1-f_{\mathrm{h}, 1}\right) \cdot C_{\text {DecompL }}
$$

where $f_{e, l}$ and $f_{h, l}$ are parameters

$$
C_{\mathrm{Humus}>\mathrm{CO}_{2}}=f_{e, \mathrm{~h}} \cdot C_{\text {DecompL }}
$$

where $f_{e, h}$ is a parameter

\section{Soil heat processes}

$$
q_{h}=-k_{h} \frac{\partial T}{\partial z}
$$

where $k_{h}$ is the conductivity, $T$ is the soil temperature and $z$ is depth.

$$
q_{h}(0)=k_{h o} \frac{\left(T_{s}-T_{1}\right)}{\Delta z / 2}+C_{w}\left(T_{s}\right) q_{\text {in }}+L_{v} q_{v o}
$$

Decomposition of the SOC pools for more stable material $\left(\mathrm{g} \mathrm{C} \mathrm{m}^{-2}\right.$ day $\left.^{-1}\right)$

Response function for soil temperature according Ratkowsky.

Response function for soil moisture (-)

Litter from inactive surface litter pool, entering the fast SOC pool at a continuous rate.

Amount of decomposition products from the fast $\mathrm{SOC}$ pools being released as $\mathrm{CO}_{2}$

Amount of decomposition products from the fast SOC pools entering the slow decomposition pools

Amount of decomposition products from the fast SOC pools being returned to the fast decomposition pools

Amount of decomposition products from the slow SOC pools being released as $\mathrm{CO}_{2}$ 
where $k_{h o}$ is the conductivity of the organic material at the surface, $T_{s}$ is the surface temperature, $T_{I}$ is the temperature in the uppermost soil layer, $q_{i n}$, is the water infiltration rate, $q_{v o}$ is the water vapour flow, and $L_{v}$ is the latent heat.

$$
k_{h o}=h_{1}+h_{2} \theta
$$

where $h_{l}$ and $h_{2}$ are empirical constants

$$
T_{s s}=\frac{T_{1}+a T_{a}}{1+a}
$$

where the index 1 means the top soil layer, and the snow surface temperature is assumed to be equal to air temperature. a is a weighting factor depending on snow thickness and conductivity in the snow pack and in the uppermost soil layer.

$$
T_{\text {LowB }}=T_{\text {amean }}-T_{\text {aamp }} e^{-\frac{z}{d_{a}}} \cos \left(\left(t-t_{p h}\right) \omega-\frac{z}{d_{a}}\right)
$$

where $T_{\text {amean }}$ and $T_{\text {aamp }}$ are parameters, $t$ is the time, $t_{p h}$ is the phase shift, $\omega$ is the frequency of the cycle and $d_{a}$ is the damping depth.

Soil water processes

$$
q_{w}=-k_{w}\left(\frac{\partial \psi}{\partial z}-1\right)-D_{v} \frac{\partial c_{v}}{\partial z}
$$

where $k_{w}$ is the unsaturated hydraulic conductivity, $\psi$ is the water tension, $z$ is depth, $c_{v}$ is the concentration of vapour in soil air and $D_{v}$ is the diffusion coefficient for vapour in the soil

$$
\frac{\partial \theta}{\partial t}=-\frac{\partial q_{w}}{\partial z}+s_{w}
$$

where $\theta$ is the soil water content and $s_{w}$ is a source/sink term for e.g. horizontal in and outflow or root water uptake.

$$
S_{e}=\left(\frac{\psi}{\psi_{a}}\right)^{-\lambda}
$$

where $\psi_{a}$ is the air-entry tension, $\lambda$ is the pore size distribution index and $S_{e}$ the effective saturation.

$$
S_{e}=\frac{\theta-\theta_{r}}{\theta_{s}-\theta_{r}}
$$

where $\theta_{s}$ is the porosity, $\theta_{r}$ is porosity content and $\theta$ is the actual water content.

$$
k_{w}^{*}=k_{m a t}\left(\frac{\psi_{a}}{\psi}\right)^{2+(2+n) \lambda}
$$

Where the matrix conductivity $k_{\text {mat }}$ is a function of the total conductivity, $n$ is a parameter accounting for pore correlation and flow path tortuosity and $\lambda$ is the pore size distribution index.

$k_{\text {mat }}=10^{\left(\log k_{\text {sat }}-\log h_{\text {com }}\right) h_{\text {sens }}+\log k_{\text {sat }}}$

(6.11) Matrix conductivity as function of total conductivity

where $h_{\text {com }}$ and $h_{\text {sens }}$ are parameters and $k_{\text {sat }}$ is the total saturated conductivity.

The general equation for unsaturated water flow follows from the law of mass conservation and eq. (30)

Effective saturation $S_{e}$, between the threshold values $\psi_{x}$ and $\psi_{\text {mat. }}$.

Unsaturated hydraulic conductivity $k_{w}^{*}$ $\left(\mathrm{mm} \mathrm{day}^{-1}\right)$ according Brooks and Corey. Corey (1965), between the threshold values $\psi_{x}$ and $\psi_{\text {mat. }}$. 


$$
q_{w p}=\int_{z_{p}}^{z_{s u t}} k_{s} \frac{\left(z_{s a t}-z_{p}\right)}{d_{u} d_{p}} d z
$$

where $d_{u}$ is the unit length of the horizontal element i.e. $1 \mathrm{~m}, z_{p}$ is the lower depth of the drainage pipe i.e. the drainage level, $z_{\text {sat }}$ is the simulated depth of the ground water table and $d_{p}$ is a characteristic distance between drainage pipes. Note that this is a simplification where the actual flow paths and the actual gradients are not represented. Only flows above the drain level $z_{p}$ are considered

$$
k_{w}^{*}=10^{\left(\log \left(k_{w}^{*}\left(\theta_{s}-\theta_{m}\right)\right)+\frac{\theta+\theta_{s}+\theta_{m}}{\theta_{m}} \log \left(\frac{k_{s a t}}{k_{w}\left(\theta_{s}-\theta_{m}\right)}\right)\right)}
$$

(6.13) Total conductivity close to saturation (above the threshold $\psi_{x}$ ), to account for the conductivity in the macro pores.

where $k_{\text {sat }}$ is the saturated total conductivity, which includes the macro pores, and $k_{w} *\left(\theta_{s}-\theta_{m}\right)$ is the hydraulic conductivity below $\theta_{s}-\theta_{m}$ (i.e. at $\psi_{\text {mat }}$ ) calculated from Eq. (51)

$$
k_{w}=\left(r_{A O T}+r_{A 1 T} T_{s}\right) \max \left(k_{w}^{*}, k_{\text {mimuc }}\right)
$$

(6.14) Actual unsaturated hydralic conductivity where $r_{A O T}, r_{A I T}$ and $k_{\text {minuc }}$ are parameter values. $k_{w}{ }^{*}$ is the conductivity according to eqs (51) and (52)
(6.12) The horizontal flow rate, $q_{w p}$, is assumed to be proportional to the hydraulic gradient and to the thickness and saturated hydraulic conductivity of each soil layer 
1 Table S3. Fixed parameters used in the main equations.

\begin{tabular}{|c|c|c|c|c|c|c|}
\hline Symbol & Parameter Name & Unit & Eq. & Module & Definition & Value \\
\hline$\eta$ & Biomass to carbon & $\begin{array}{l}\mathrm{mol} \mathrm{C} \\
g^{-1} \mathrm{dw}\end{array}$ & 1.1 & $\begin{array}{l}\text { Plant biomass:C } \\
\text { ratio }\end{array}$ & $\begin{array}{l}\text { Conversion factor from biomass } \\
\text { to carbon }\end{array}$ & 0.45 \\
\hline$p_{m x}$ & PhoTempResMax & ${ }^{\circ} \mathrm{C}$ & 1.2 & $\begin{array}{l}\text { Plant } \\
\text { assimilation: } \\
\text { temperature } \\
\text { response }\end{array}$ & $\begin{array}{l}\text { Maximum mean air temperature } \\
\text { for photosynthesis }\end{array}$ & 45 \\
\hline$l_{c l}$ & Leaf c1(1) & $\mathrm{g} \mathrm{C}^{-1}$ & $\begin{array}{l}1.4 \\
1.5\end{array}$ & $\begin{array}{l}\text { Plant allocation } \\
\text { of assimilates to } \\
\text { the leaves }\end{array}$ & $\begin{array}{l}\text { Fraction of new assimilates } \\
\text { which is allocated to the leaves }\end{array}$ & 0.545 \\
\hline $\begin{array}{l}k_{\text {mrespleaf, }} \\
\text { vasc }\end{array}$ & MCoefLeaf(1) & day $^{-1}$ & 1.6 & Plant respiration & $\begin{array}{l}\text { Rate coefficient for maintenance } \\
\text { respiration of vascular plant leaves } \\
\text { (respiration relative to leaf } \\
\text { biomass) }\end{array}$ & $\begin{array}{l}0.002 \\
5\end{array}$ \\
\hline $\begin{array}{l}k_{\text {mresproot, }} \\
\text { vasc }\end{array}$ & MCoefRoot(1) & day $^{-1}$ & 1.6 & Plant respiration & $\begin{array}{l}\text { Maintenance respiration } \\
\text { coefficient for vascular plant root } \\
\text { (respiration relative to root } \\
\text { biomass) }\end{array}$ & $\begin{array}{l}0.002 \\
5\end{array}$ \\
\hline $\begin{array}{l}k_{\text {mrespstem, }} \\
\text { moss }\end{array}$ & MCoefStem(1) & day $^{-1}$ & 1.6 & Plant respiration & $\begin{array}{l}\text { Maintenance respiration } \\
\text { coefficient for vascular plant stem } \\
\text { = photosynthetically inactive } \\
\text { biomass like e.g. senescent leaves } \\
\text { that are still attached to the plant } \\
\text { (respiration relative to stem } \\
\text { biomass) }\end{array}$ & 0 \\
\hline $\begin{array}{l}k_{\text {mrespleaf, }} \\
\text { moss }\end{array}$ & MCoefLeaf(2) & day $^{-1}$ & 1.6 & Plant respiration & $\begin{array}{l}\text { Rate coefficient for maintenance } \\
\text { respiration of moss leaves } \\
\text { (respiration relative to leaf } \\
\text { biomass) }\end{array}$ & 0 \\
\hline $\begin{array}{l}k_{\text {mresproot, }} \\
\text { moss }\end{array}$ & MCoefRoot(2) & day $^{-1}$ & 1.6 & Plant respiration & $\begin{array}{l}\text { Maintenance respiration } \\
\text { coefficient for moss "root" = } \\
\text { leaves and stem below the capita } \\
\text { (respiration relative to root } \\
\text { biomass) }\end{array}$ & $\begin{array}{l}0.002 \\
5\end{array}$ \\
\hline$t_{\text {Q10bas }}$ & TemQ10Bas & ${ }^{\circ} \mathrm{C}$ & 1.7 & $\begin{array}{l}\text { Plant respiration: } \\
\text { Temperature } \\
\text { response }\end{array}$ & $\begin{array}{l}\text { Base temperature for the } \\
\text { temperature response of plant } \\
\text { respriation, at which the response } \\
\text { is } 1\end{array}$ & 20 \\
\hline$S_{\text {newstem }}$ & New Stem(1) & - & & Plant litter fall & $\begin{array}{l}\text { Scaling factor for litter fall from } \\
\text { new stems }\end{array}$ & 1 \\
\hline$l_{S c I}$ & StemRate1(1) & day $^{-1}$ & 1.10 & Plant litter fall & $\begin{array}{l}\text { Rate coefficient for the litter fall } \\
\text { from stems before the first } \\
\text { threshold temperature sum } t_{S I} \text { is } \\
\text { reached }\end{array}$ & 0.05 \\
\hline$l_{S c 2}$ & StemRate2(1) & day $^{-1}$ & 1.10 & Plant litter fall & $\begin{array}{l}\text { Rate coefficient for the litter fall } \\
\text { from stems after the second } \\
\text { threshold temperature sum } t_{S 2} \text { is } \\
\text { reached }\end{array}$ & 0.5 \\
\hline$S_{\text {newleaf }}$ & New Leaf & - & & Plant litter fall & $\begin{array}{l}\text { Scaling factor for litter fall from } \\
\text { new leaves }\end{array}$ & 1 \\
\hline$l_{L c 2}$ & LeafRate2(1) & day $^{-1}$ & 1.10 & $\begin{array}{l}\text { Plant litter fall: } \\
\text { leaf litter fall rate } \\
\text { at the end of the } \\
\text { season }\end{array}$ & $\begin{array}{l}\text { Rate coefficient for the leaf litter } \\
\text { fall after the second threshold } \\
\text { temperature sum } t_{L 2} \text { is reached }\end{array}$ & 0.5 \\
\hline$t_{L I}$ & LeafTsum1(1) & $\operatorname{day}^{\circ} \mathrm{C}$ & 1.10 & Plant litter fall & $\begin{array}{l}\text { Threshold temperature sum after } \\
\text { reaching dormancy state for the } \\
\text { lower leaf litter rate. When it is } \\
\text { reached, } l_{L c 1} \text { starts to change } \\
\text { towards the increased litter fall rate } \\
l_{L c 2}\end{array}$ & 2 \\
\hline$t_{L 2}$ & LeafTsum2(1) & $\operatorname{day}^{\circ} \mathrm{C}$ & 1.10 & Plant litter fall & $\begin{array}{l}\text { Threshold temperature sum after } \\
\text { reaching dormancy state for the } \\
\text { higher leaf litter rate. When it is } \\
\text { reached, the full high litter rate is } \\
\text { applied. }\end{array}$ & 14 \\
\hline$t_{S 1}$ & StemTsum1(1) & $\operatorname{day}^{\circ} \mathrm{C}$ & 1.10 & Plant litter fall & $\begin{array}{l}\text { Threshold temperature sum after } \\
\text { reaching dormancy state for the } \\
\text { lower stem litter rate. When it is } \\
\text { reached, } \mathrm{t}_{S c l} \text { starts to change }\end{array}$ & 2 \\
\hline
\end{tabular}

No leaf respiration for mosses to allow a fixed moss capita

No respiration, as this represents brown, senescent biomass

002 Based on results from a pre-study calibration with the site data.

Default value

Full litterfall rate applies, no scaling Based on results from a pre-study calibration with the site data.

Based on results from a pre-study calibration with the site data.

Full litterfall rate applies, no scaling Based on results from a pre-study calibration with the site data.

Based on results from a pre-study calibration with the site data.

Based on results from a pre-study calibration with the site data.

Based on results from a pre-study calibration with the site data. 


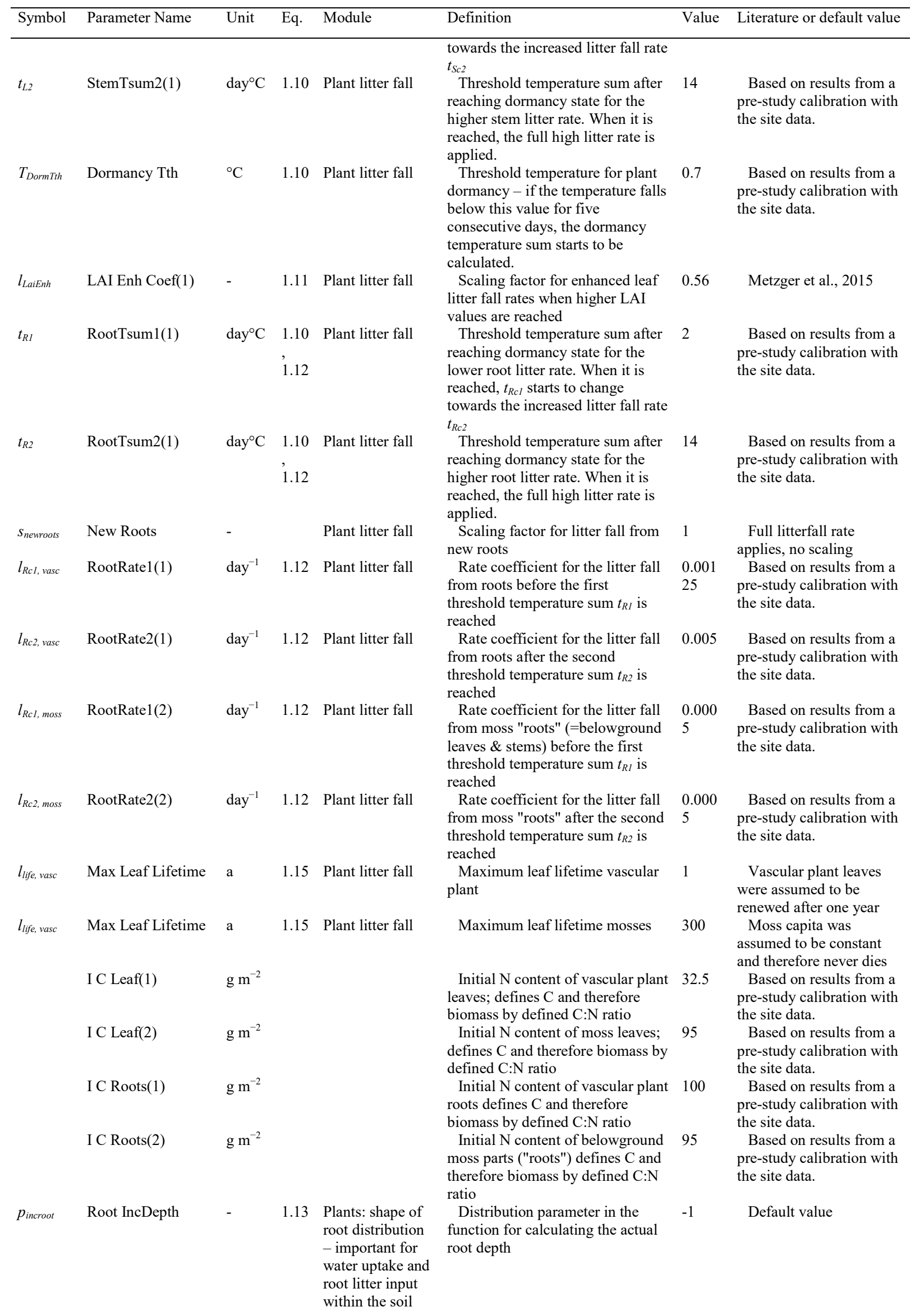




\begin{tabular}{|c|c|c|c|c|c|c|c|}
\hline Symbol & Parameter Name & Unit & Eq. & Module & Definition & Value & Literature or default value \\
\hline & & & & profile & & & \\
\hline$m_{\text {shoot }}$ & Shoot Coef & - & 1.16 & $\begin{array}{l}\text { Plant storage } \\
\text { pool for regrowth } \\
\text { in spring }\end{array}$ & $\begin{array}{l}\text { Coefficient for the rate at which } \\
\mathrm{C} \text { is reallocated from the mobile } \\
\text { pool to the leaf at leafing }\end{array}$ & 0.07 & $\begin{array}{l}\text { Based on results from a } \\
\text { pre-study calibration with } \\
\text { the site data. }\end{array}$ \\
\hline$k_{r n}$ & RntLAI & - & 2.1 & $\begin{array}{l}\text { Plant radiation } \\
\text { interception: } \\
\text { partitioning } \\
\text { between plants } \\
\text { and soil }\end{array}$ & $\begin{array}{l}\text { Extinction coefficient in the } \\
\text { Beer's law used to calculate the } \\
\text { partitioning of net radiation } \\
\text { between canopy and soil surface }\end{array}$ & 0.8 & $\begin{array}{l}\text { Based on results from a } \\
\text { pre-study calibration with } \\
\text { the site data. }\end{array}$ \\
\hline$p_{c m a x, v a s c}$ & Maximal Cover(1) & $\begin{array}{l}\mathrm{m}^{2} \\
\mathrm{~m}^{-2}\end{array}$ & 2.2 & $\begin{array}{l}\text { Radiation } \\
\text { interception: } \\
\text { Plant coverage }\end{array}$ & $\begin{array}{l}\text { Maximum surface cover of } \\
\text { vascular plants }\end{array}$ & 0.6 & $\begin{array}{l}\text { Visually estimated plant } \\
\text { coverage at the site }\end{array}$ \\
\hline$p_{\text {cmax, moss }}$ & Maximal Cover(2) & $\begin{array}{l}\mathrm{m}^{2} \\
\mathrm{~m}^{-2}\end{array}$ & 2.2 & $\begin{array}{l}\text { Radiation } \\
\text { interception: } \\
\text { Plant coverage }\end{array}$ & $\begin{array}{l}\text { Maximum surface cover of } \\
\text { mosses }\end{array}$ & 1 & $\begin{array}{l}\text { Visually estimated plant } \\
\text { coverage at the site }\end{array}$ \\
\hline$p_{c k}$ & Area kExp(1) & - & 2.2 & $\begin{array}{l}\text { Radiation } \\
\text { interception: } \\
\text { Plant coverage }\end{array}$ & $\begin{array}{l}\text { Speed at which the maximum } \\
\text { surface cover of the plant canopy } \\
\text { is reached }\end{array}$ & 1 & $\begin{array}{l}\text { Based on results from a } \\
\text { pre-study calibration with } \\
\text { the site data. }\end{array}$ \\
\hline$p_{l, s p}$ & Specific LeafArea & $\begin{array}{l}\mathrm{g} \mathrm{C} \\
\mathrm{m}^{-2}\end{array}$ & 2.3 & $\begin{array}{l}\text { Plant } \\
\text { LAI:phytomass } \\
\text { ratio }\end{array}$ & $\begin{array}{l}\text { Factor for calculating LAI from } \\
\text { leaf biomass, which is actually the } \\
\text { inverse of specific leaf area, i.e. } \\
\text { leaf mass per unit leaf }\end{array}$ & 47.5 & Metzger et al., 2015 \\
\hline$T_{\text {EmergeTh }}$ & TempSumCrit & ${ }^{\circ} \mathrm{C}$ & & $\begin{array}{l}\text { Plant phenology: } \\
\text { start of growing } \\
\text { season }\end{array}$ & $\begin{array}{l}\text { Critical air temperature that must } \\
\text { be exceeded for temperature sum } \\
\text { calculation }\end{array}$ & 5 & Default value \\
\hline $\begin{array}{l}T_{\text {EmergeSu }} \\
m\end{array}$ & TempSumStart & ${ }^{\circ} \mathrm{C}$ & & $\begin{array}{l}\text { Plant phenology: } \\
\text { start of growing } \\
\text { season }\end{array}$ & $\begin{array}{l}\text { Air temperature sum which is the } \\
\text { threshold for start of plant } \\
\text { development }\end{array}$ & 50 & Default value \\
\hline$p_{\text {densm, vasc }}$ & $\begin{array}{l}\text { Canopy } \\
\text { DensMax(1) }\end{array}$ & - & 2.8 & $\begin{array}{l}\text { Plant: density of } \\
\text { vascular plant } \\
\text { canopy }\end{array}$ & $\begin{array}{l}\text { The density maximum of canopy } \\
\text { in relation to the canopy height }\end{array}$ & 0.7 & Default value \\
\hline $\begin{array}{l}p_{\text {densm, }} \\
\text { moss }\end{array}$ & $\begin{array}{l}\text { Canopy } \\
\text { DensMax(2) }\end{array}$ & - & 2.8 & $\begin{array}{l}\text { Plant: density of } \\
\text { moss canopy }\end{array}$ & $\begin{array}{l}\text { The density maximum of canopy } \\
\text { in relation to the canopy height }\end{array}$ & 0.9 & Estimation for the site \\
\hline$g_{r i s}$ & CondRis & $\begin{array}{l}\mathrm{J} \mathrm{m}^{-2} \\
\text { day }^{-1}\end{array}$ & 2.10 & $\begin{array}{l}\text { Plant } \\
\text { assimilation: } \\
\text { radiation } \\
\text { saturation }\end{array}$ & $\begin{array}{l}\text { Global radiation intensity that } \\
\text { represents half-light saturation in } \\
\text { the light response }\end{array}$ & $5 \cdot 10^{6}$ & Default value \\
\hline$c_{H O, \text { canopy }}$ & $\begin{array}{l}\text { WindLessExchange } \\
\text { Canopy }\end{array}$ & $\mathrm{m} \mathrm{s}^{-1}$ & 2.6 & $\begin{array}{l}\text { Aerodynamic } \\
\text { resistance of } \\
\text { canopy: } \\
\text { minimum } \\
\text { exchange under } \\
\text { stabile conditions }\end{array}$ & $\begin{array}{l}\text { Roughness length used in the } \\
\text { calculation of ra for each plant, } \\
\text { corresponds to } z 0 \text { in eq. } 2.6 \text {. }\end{array}$ & 0.001 & Default value \\
\hline$z_{r e f}$ & ReferenceHeight & $\mathrm{m}$ & 2.6 & $\begin{array}{l}\text { Aerodynamic } \\
\text { resistance of } \\
\text { canopy: } \\
\text { minimum } \\
\text { exchange under } \\
\text { stabile conditions }\end{array}$ & $\begin{array}{l}\text { Height above ground which } \\
\text { represent the level for measured air } \\
\text { temperature, air humidity and wind } \\
\text { speed. }\end{array}$ & 2 & Default value \\
\hline$z_{0 \max }$ & Roughness Max & $\mathrm{m}$ & 2.7 & $\begin{array}{l}\text { Aerodynamic } \\
\text { resistance: } \\
\text { roughness length } \\
\text { of plants }\end{array}$ & $\begin{array}{l}\text { The maximum roughness length } \\
\text { used when estimating roughness } \\
\text { length of different canopies (see } \\
\text { "Aerodynamic resistance"). }\end{array}$ & 3 & Default value \\
\hline$z_{\text {Omin }}$ & Roughness Min & $\mathrm{m}$ & 2.7 & $\begin{array}{l}\text { Aerodynamic } \\
\text { resistance: } \\
\text { roughness length } \\
\text { of plants }\end{array}$ & $\begin{array}{l}\text { The minimum roughness length } \\
\text { used when estimating roughness } \\
\text { length of different canopies }\end{array}$ & 0.01 & Default value \\
\hline$g_{v p d}$ & CondVPD & $\mathrm{Pa}$ & 2.10 & $\begin{array}{l}\text { Transpiration } \\
\text { stress due to low } \\
\text { air humidity }\end{array}$ & $\begin{array}{l}\text { Vapour pressure deficit that } \\
\text { corresponds to a } 51 \% \text { reduction of } \\
\text { stomata conductance }\end{array}$ & 100 & Default value \\
\hline$p_{2}$ & $\begin{array}{l}\text { NonDemandRelCo } \\
\text { ef }\end{array}$ & $\begin{array}{l}\mathrm{kg} \\
\mathrm{m}^{-2} \\
\text { day }^{-1}\end{array}$ & 27 & $\begin{array}{l}\text { Transpiration } \\
\text { stress due to too } \\
\text { low water } \\
\text { content }\end{array}$ & $\begin{array}{l}\text { Coefficient in moisture reduction } \\
\text { function. The degree of reduction } \\
\text { when the actual pressure head } \\
\text { exceeds the critical threshold, } \psi_{c} \text {, } \\
\text { is controlled by this coefficient } \\
\text { together with } p 1 \text { and the potential } \\
\text { transpiration rate, Etp. }\end{array}$ & 0.1 & Default value \\
\hline$p_{o x}$ & AirRedCoef & - & 28 & $\begin{array}{l}\text { Transpiration } \\
\text { and assimilation } \\
\text { stress due to high }\end{array}$ & $\begin{array}{l}\text { A rate coefficient that governs } \\
\text { how rapidly the plant resistance } \\
\text { will increase because of the lack of }\end{array}$ & 0 & $\begin{array}{l}\text { The plants are assumed } \\
\text { to be well adapted to wet } \\
\text { conditions and therefore }\end{array}$ \\
\hline
\end{tabular}




\begin{tabular}{|c|c|c|c|c|c|c|c|}
\hline Symbol & Parameter Name & Unit & Eq. & Module & Definition & Value & Literature or default value \\
\hline$\theta_{\text {Amin }}$ & AirMinContent & vol \% & 29 & $\begin{array}{l}\text { Transpiration } \\
\text { and assimilation } \\
\text { stress due to high } \\
\text { water content }\end{array}$ & $\begin{array}{l}\text { oxygen when the water content of } \\
\text { the soil exceeds the value give by } \\
\text { the actual soil moisture content, } \theta \\
\text { The minimum amount of air that } \\
\text { is necessary to prevent any } \\
\text { reduced uptake of water from the } \\
\text { soil }\end{array}$ & 0 & $\begin{array}{l}\text { do not suffer from water } \\
\text { stress due to too wet } \\
\text { conditions } \\
\text { The plants are assumed } \\
\text { to be well adapted to wet } \\
\text { conditions and therefore } \\
\text { do not suffer from water } \\
\text { stress due to too wet } \\
\text { conditions }\end{array}$ \\
\hline$t_{W B}$ & TempCoefB & - & 2.13 & $\begin{array}{l}\text { Transpiration } \\
\text { stress due to } \\
\text { limited water } \\
\text { availability under } \\
\text { low temperatures }\end{array}$ & $\begin{array}{l}\text { Temperature coefficient in the } \\
\text { temperature response function. }\end{array}$ & 0.4 & Default value \\
\hline$t_{W C}$ & TempCoefC & - & & $\begin{array}{l}\text { Transpiration } \\
\text { stress due to } \\
\text { limited water } \\
\text { availability under } \\
\text { low temperatures }\end{array}$ & $\begin{array}{l}\text { Temperature coefficient } \\
\text { governing the trigging } \\
\text { temperature. }\end{array}$ & 0 & Default value \\
\hline$r_{a, \text { soil } \max }{ }^{-1}$ & $\begin{array}{l}\text { WindLessExchange } \\
\text { Soil }\end{array}$ & - & 3.4 & $\begin{array}{l}\text { Aerodynamic } \\
\text { resistance: upper } \\
\text { limit under } \\
\text { windless } \\
\text { conditions }\end{array}$ & $\begin{array}{l}\text { Minimum turbulent exchange } \\
\text { coefficient (inverse of maximum } \\
\text { allowed aerodynamic resistance) } \\
\text { over bare soil. Avoids exaggerated } \\
\text { surface cooling in windless } \\
\text { conditions or extreme stable } \\
\text { stratification. }\end{array}$ & 0.001 & Default value \\
\hline$z_{O M}$ & $\begin{array}{l}\text { RoughLBareSoilM } \\
\text { om }\end{array}$ & $\mathrm{m}$ & 3.4 & $\begin{array}{l}\text { Aerodynamic } \\
\text { resistance: } \\
\text { roughness length } \\
\text { of bare soil }\end{array}$ & $\begin{array}{l}\text { Surface roughness length for } \\
\text { momentum above bare soil. }\end{array}$ & 0.001 & Default value \\
\hline$s_{\text {excess }}$ & MaxSurfExcess & $\mathrm{mm}$ & 3.7 & $\begin{array}{l}\text { Vapour pressure } \\
\text { at the soil surface }\end{array}$ & $\begin{array}{l}\text { The highest value allowed for the } \\
\delta_{\text {surf }} \text { variable, which is used in the } \\
\text { calculations of soil surface } \\
\text { resistance and vapour pressure at } \\
\text { the soil surface. }\end{array}$ & 1 & Default value \\
\hline$s_{\text {def }}$ & MaxSurfDeficit & $\mathrm{mm}$ & 3.7 & $\begin{array}{l}\text { Vapour pressure } \\
\text { at the soil surface }\end{array}$ & $\begin{array}{l}\text { The lowest value allowed for the } \\
\delta_{\text {surf }} \text { variable, which is used in the } \\
\text { calculations of soil surface } \\
\text { resistance and vapour pressure at } \\
\text { the soil surface. }\end{array}$ & -2 & Default value \\
\hline$d_{v a p b}$ & DVapTortuosity & - & 3.9 & & $\begin{array}{l}\text { Correction factor because of non- } \\
\text { perfect condition for diffusion }\end{array}$ & 0.66 & Default value \\
\hline$k_{\text {matt }}$ & $\begin{array}{l}\text { Matrix } \\
\text { Conductivity }\end{array}$ & $\begin{array}{l}\mathrm{mm} \\
\text { day }^{-1}\end{array}$ & 6.10 & $\begin{array}{l}\text { Soil hydraulic } \\
\text { conductivity: } \\
\text { temperature } \\
\text { dependence }\end{array}$ & Saturated matrix conductivity & 100 & Default value \\
\hline$\theta_{s}$ & Saturation & vol \% & $\begin{array}{l}5.4 \\
6.9\end{array}$ & $\begin{array}{l}\text { Soil hydraulic } \\
\text { properties: shape } \\
\text { of water } \\
\text { retention }\end{array}$ & Water content at saturation & $\begin{array}{l}98 \\
(95)\end{array}$ & $\begin{array}{l}\text { Received by comparing } \\
\text { resulting pF curves with } \\
\text { curves measured in } \\
\text { peatlands (Kellner and } \\
\text { Lundin, 2001) under } \\
\text { consideration of the range } \\
\text { for the calibrated } \\
\text { parameter AirEntry; the } \\
\text { value in brackets is used } \\
\text { for layers below }-30 \mathrm{~cm}\end{array}$ \\
\hline$\theta_{\text {wilt }}$ & Wilting Point & vol \% & 5.4 & $\begin{array}{l}\text { Soil hydraulic } \\
\text { properties: shape } \\
\text { of water } \\
\text { retention }\end{array}$ & Water content at wilting point & $\begin{array}{l}30 \\
(30)\end{array}$ & $\begin{array}{l}\text { Received by comparing } \\
\text { resulting pF curves with } \\
\text { curves measured in } \\
\text { peatlands (Kellner and } \\
\text { Lundin } 2001 \text { ) under } \\
\text { consideration of the range } \\
\text { for the calibrated } \\
\text { parameter AirEntry; the } \\
\text { value in brackets is used } \\
\text { for layers below }-30 \mathrm{~cm}\end{array}$ \\
\hline$\psi_{x}$ & Upper Boundary & $\mathrm{cm}$ & $\begin{array}{l}6.8 \\
6.9 \\
6.13\end{array}$ & $\begin{array}{l}\text { Soil hydraulic } \\
\text { properties: shape } \\
\text { of water } \\
\text { retention }\end{array}$ & $\begin{array}{l}\text { Soil water tension at the upper } \\
\text { boundary of Brooks and Corey's } \\
\text { expression }\end{array}$ & 8000 & Default value \\
\hline
\end{tabular}




\begin{tabular}{|c|c|c|c|c|c|c|c|}
\hline Symbol & Parameter Name & Unit & Eq. & Module & Definition & Value & Literature or default value \\
\hline$\lambda$ & Lambda & - & $\begin{array}{l}6.8 \\
6.10\end{array}$ & $\begin{array}{l}\text { Soil hydraulic } \\
\text { properties: shape } \\
\text { of water } \\
\text { retention }\end{array}$ & Pore size distribution index & $\begin{array}{l}0.3 \\
(0.2)\end{array}$ & $\begin{array}{l}\text { Received by comparing } \\
\text { resulting pF curves with } \\
\text { curves measured in } \\
\text { peatlands (Kellner and } \\
\text { Lundin 2001) under } \\
\text { consideration of the range } \\
\text { for the calibrated } \\
\text { parameter AirEntry; the } \\
\text { value in brackets is used } \\
\text { for layers below }-30 \mathrm{~cm}\end{array}$ \\
\hline$z$ & LowerDepth & $\mathrm{m}$ & & $\begin{array}{l}\text { Soil hydraulic } \\
\text { properties: } \\
\text { Border between } \\
\text { horizons }\end{array}$ & $\begin{array}{l}\text { Depth of the border between the } \\
\text { upper and lower horizon in respect } \\
\text { to hydrological properties }\end{array}$ & 0.3 & $\begin{array}{l}\text { Boundary between } \\
\text { acrotelm and catotelm, } \\
\text { based on visual } \\
\text { differences in the soil } \\
\text { profile and water table } \\
\text { depth measurements } \\
\text { (Granberg et al., 1999). }\end{array}$ \\
\hline$h_{1}$ & OrganicC1 & - & 6.3 & $\begin{array}{l}\text { Soil temperature } \\
\text { - thermal } \\
\text { conductivity }\end{array}$ & $\begin{array}{l}\text { Empirical constant in the heat } \\
\text { conductivity of the organic } \\
\text { material at the surface }\end{array}$ & 0.06 & Default value \\
\hline$T_{\text {aamp }}$ & TempAirAmpl & ${ }^{\circ} \mathrm{C}$ & 6.5 & $\begin{array}{l}\text { Soil temperature } \\
\text { - lower boundary }\end{array}$ & $\begin{array}{l}\text { Assumed value of the amplitude } \\
\text { of the sine curve, representing the } \\
\text { lower boundary condition for heat } \\
\text { conduction }\end{array}$ & 10 & Default value \\
\hline$\Delta z_{\text {humus }}$ & OrganicLayerThick & $\mathrm{m}$ & & $\begin{array}{l}\text { Soil thermal } \\
\text { properties }\end{array}$ & $\begin{array}{l}\text { Thickness of the humus layer as } \\
\text { used as a thermal property }\end{array}$ & 3 & $\begin{array}{l}\text { Site specific value for } \\
\text { peat depth. Measurements } \\
\text { at the site indicate a peat } \\
\text { depth of } 3-4 \mathrm{~m}\end{array}$ \\
\hline$\theta_{r}$ & Residual Water & vol \% & 6.9 & $\begin{array}{l}\text { Soil hydraulic } \\
\text { properties: shape } \\
\text { of water } \\
\text { retention }\end{array}$ & Residual soil water content & $1(1)$ & $\begin{array}{l}\text { Received by comparing } \\
\text { resulting pF curves with } \\
\text { curves measured in } \\
\text { peatlands (Kellner and } \\
\text { Lundin 2001) under } \\
\text { consideration of the range } \\
\text { for the calibrated } \\
\text { parameter AirEntry; The } \\
\text { value in brackets is used } \\
\text { for layers below }-30 \mathrm{~cm}\end{array}$ \\
\hline$n$ & n Tortuosity & - & 6.10 & $\begin{array}{l}\text { Unsaturated soil } \\
\text { hydraulic } \\
\text { conductivity of } \\
\text { soil }\end{array}$ & $\begin{array}{l}\text { Parameter for pore correlation } \\
\text { and flow path tortuosity in the } \\
\text { function for unsaturated hydraulic } \\
\text { conductivity }\end{array}$ & $1(1)$ & $\begin{array}{l}\text { Based on results from a } \\
\text { pre-study calibration with } \\
\text { the site data. The value in } \\
\text { brackets is used for layers } \\
\text { below }-30 \mathrm{~cm}\end{array}$ \\
\hline \multirow[t]{2}{*}{$z_{p}$} & DrainLevel & $\mathrm{m}$ & 6.12 & $\begin{array}{l}\text { Soil water: } \\
\text { drainage depth }\end{array}$ & Lower depth of the drainage & -0.12 & $\begin{array}{l}\text { Measured water level } \\
\text { during wet periods at the } \\
\text { site }\end{array}$ \\
\hline & DrainLevelMin & $\mathrm{m}$ & & $\begin{array}{l}\text { Soil water: } \\
\text { minimum drain } \\
\text { level }\end{array}$ & Lowest possible water level & -0.6 & $\begin{array}{l}\text { Well below the lowest } \\
\text { measured water table at } \\
\text { that site }(0.4) \text {. }\end{array}$ \\
\hline$\theta_{m}$ & Macro Pore & vol \% & 6.13 & $\begin{array}{l}\text { Soil hydraulic } \\
\text { properties: shape } \\
\text { of water } \\
\text { retention }\end{array}$ & Macro pore volume & $4(4)$ & $\begin{array}{l}\text { Received by comparing } \\
\text { resulting pF curves with } \\
\text { curves measured in } \\
\text { peatlands (Kellner and } \\
\text { Lundin } 2001 \text { ) under } \\
\text { consideration of the range } \\
\text { for the calibrated } \\
\text { parameter AirEntry; the } \\
\text { value in brackets is used } \\
\text { for layers below }-30 \mathrm{~cm}\end{array}$ \\
\hline$k_{\text {sat }}$ & Total Conductivity & $\begin{array}{l}\mathrm{mm} \\
\text { day }^{-1}\end{array}$ & $\begin{array}{l}6.11 \\
6.13\end{array}$ & $\begin{array}{l}\text { Saturated soil } \\
\text { hydraulic } \\
\text { conductivity of } \\
\text { soil }\end{array}$ & $\begin{array}{l}\text { Total conductivity under } \\
\text { saturated conditions }\end{array}$ & $\begin{array}{l}1610 \\
(800)\end{array}$ & $\begin{array}{l}\text { From measured dry bulk } \\
\text { density according } \\
\text { Päivänen, } 1973\end{array}$ \\
\hline $\mathrm{r}_{A I T}$ & $\begin{array}{l}\text { TempFacLinlncreas } \\
\text { e }\end{array}$ & ${ }^{\circ} \mathrm{C}^{-1}$ & 6.14 & $\begin{array}{l}\text { Soil hydraulic } \\
\text { conductivity: } \\
\text { temperature } \\
\text { dependence }\end{array}$ & $\begin{array}{l}\text { The slope coefficient in a linear } \\
\text { temperature dependence function } \\
\text { for the hydraulic conductivity }\end{array}$ & 0.023 & Default value \\
\hline $\mathrm{r}_{A O T}$ & TempFacAtZero & - & 6.14 & $\begin{array}{l}\text { Soil hydraulic } \\
\text { conductivity: } \\
\text { temperature } \\
\text { dependence }\end{array}$ & $\begin{array}{l}\text { Relative hydraulic conductivity } \\
\text { at } 0^{\circ} \mathrm{C} \text { compared with a reference } \\
\text { temperature of } 20^{\circ} \mathrm{C} \text {. }\end{array}$ & 0.55 & Default value \\
\hline
\end{tabular}




\begin{tabular}{|c|c|c|c|c|c|c|c|}
\hline Symbol & Parameter Name & Unit & Eq. & Module & Definition & Value & Literature or default value \\
\hline $\mathrm{k}_{\text {minuc }}$ & $\begin{array}{l}\text { MinimumCondVal } \\
\text { ue }\end{array}$ & $\mathrm{day}^{-1}$ & 6.14 & $\begin{array}{l}\text { Soil hydraulic } \\
\text { conductivity }\end{array}$ & $\begin{array}{l}\text { The minimum hydraulic } \\
\text { conductivity in the hydraulic } \\
\text { conductivity function. }\end{array}$ & $1 \cdot 10^{-5}$ & Default value \\
\hline $\mathrm{f}_{e, l}$ & Eff Litter1\&2 & day $^{-1}$ & $\begin{array}{l}5.6 \\
5.7 \\
5.8\end{array}$ & $\begin{array}{l}\text { SOC } \\
\text { decomposition }\end{array}$ & $\begin{array}{l}\text { Fraction of decomposition } \\
\text { products from the fast SOC pools } \\
\text { being released as } \mathrm{CO}_{2}\end{array}$ & 0.5 & Default value \\
\hline $\mathrm{f}_{h, l}$ & HumFracLitter1\&2 & day $^{-1}$ & $\begin{array}{l}5.6 \\
5.7 \\
5.8\end{array}$ & $\begin{array}{l}\text { SOC } \\
\text { decomposition }\end{array}$ & $\begin{array}{l}\text { Fraction of decomposition } \\
\text { products from the fast SOC pools } \\
\text { that will enter the slow } \\
\text { decomposition pools }\end{array}$ & 0.2 & Default value \\
\hline $\mathrm{p}_{\theta p}$ & ThetaPowerCoef & vol \% & 5.4 & $\begin{array}{l}\text { SOC } \\
\text { decomposition - } \\
\text { water response }\end{array}$ & $\begin{array}{l}\text { Power coefficient in the response } \\
\text { function of microbial activity in } \\
\text { dependency of soil moisture }\end{array}$ & 1 & Default value \\
\hline $1_{l I}$ & $\begin{array}{l}\text { RateCoefSurf } \\
\text { L1\&2 }\end{array}$ & day $^{-1}$ & 5.5 & $\begin{array}{l}\text { SOC } \\
\text { decomposition }\end{array}$ & $\begin{array}{l}\text { Fraction of the above ground } \\
\text { residues that enter the pool for fast } \\
\text { decomposition of the uppermost } \\
\text { soil layer }\end{array}$ & 0.005 & Default value \\
\hline $\mathrm{f}_{e, h}$ & Eff Humus & day $^{-1}$ & 5.9 & $\begin{array}{l}\text { SOC } \\
\text { decomposition }\end{array}$ & $\begin{array}{l}\text { Fraction of decomposition } \\
\text { products from the slow SOC pools } \\
\text { being released as } \mathrm{CO}_{2}\end{array}$ & 0.5 & Default value \\
\hline \multirow[t]{2}{*}{$\mathrm{cn}_{m}$} & CN Ratio Microbe & - & & $\begin{array}{l}\text { SOC } \\
\text { decomposition }\end{array}$ & $\begin{array}{l}\text { Litter quality at which } \\
\text { decomposers shift from } \\
\text { immobilisation of mineral } \mathrm{N} \text { to net } \\
\text { mineralisation }\end{array}$ & 30 & $\begin{array}{l}\text { Based on results from a } \\
\text { pre-study calibration with } \\
\text { the site data. }\end{array}$ \\
\hline & Latitude & - & & & $\begin{array}{l}\text { Geographic position; used for the } \\
\text { calculation of cloudiness }\end{array}$ & 65.18 & Location of the site \\
\hline
\end{tabular}


1 Table S4. Correlation coefficients between parameters and performance. The maximum value

2 is shown if a parameter correlated with several performance indices or several sub periods of

3 the same variable. The first two digits after decimal point are displayed. Values $<0.14$ are not 4 shown.

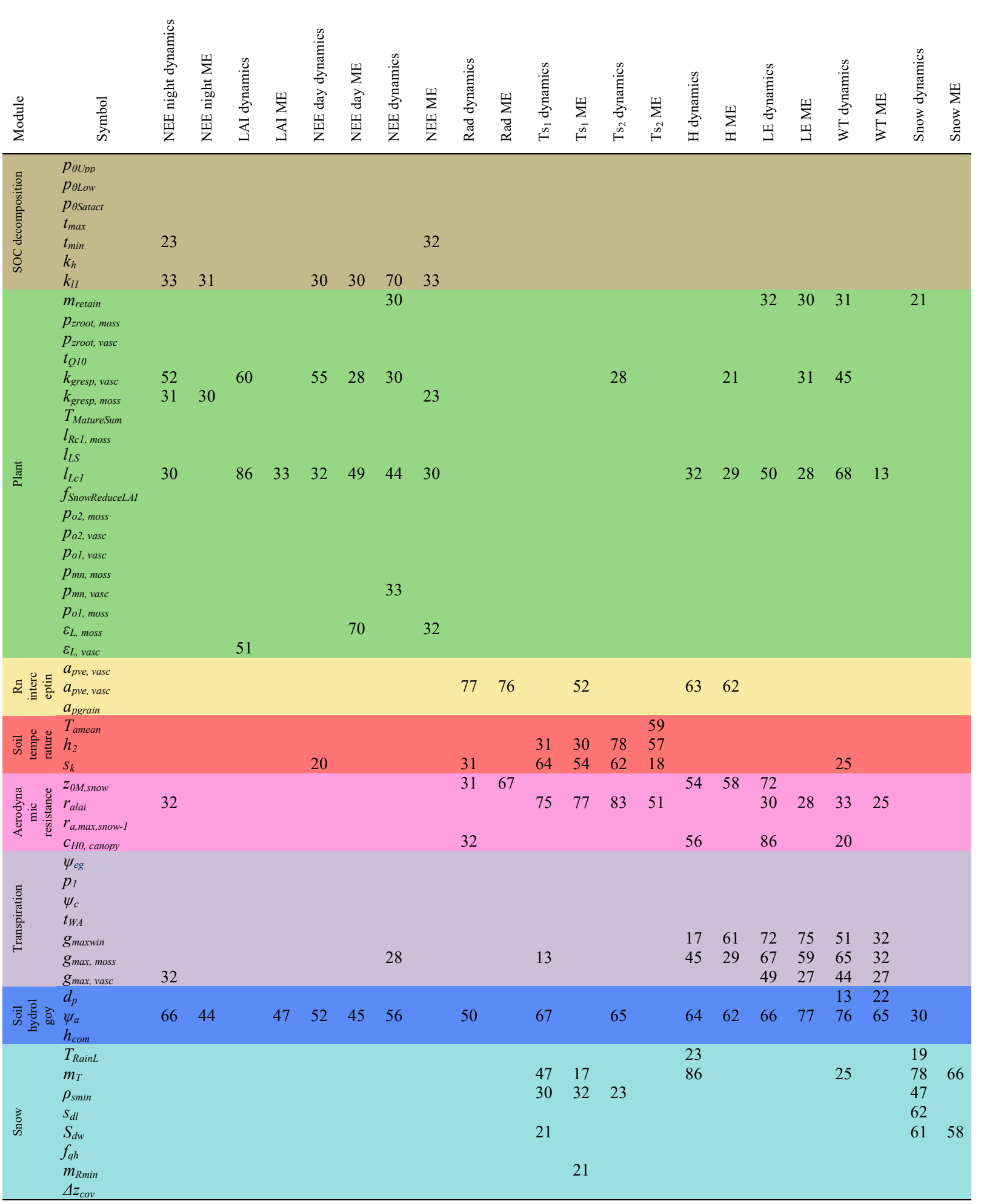


1 Table S5. Prior and posterior parameter ranges of the basic selection. Deviations of parameter

2 ranges from the prior, after applying the basic criteria. Only parameters with a deviation are 3 shown. The deviation is given in percentage of the prior range.

\begin{tabular}{|c|c|c|c|c|c|c|c|c|c|c|c|}
\hline & Max & & $\psi_{a}$ & & $k_{\text {gresp,vasc }}$ & $m_{\text {retain }}$ & $\varepsilon_{L, \text { vasc }}$ & $g_{\max , \operatorname{moss}}$ & $l_{L c 1}$ & & \\
\hline Min Range deviation & & $3 \%$ & & $3 \%$ & $0 \%$ & $0 \%$ & $0 \%$ & $0 \%$ & & $0 \%$ & $0 \%$ \\
\hline Max Range deviation & & $1 \%$ & & $1 \%$ & $0 \%$ & $0 \%$ & $0 \%$ & $0 \%$ & & $0 \%$ & $0 \%$ \\
\hline Mean Range deviation & & $13 \%$ & & $8 \%$ & $13 \%$ & $8 \%$ & $10 \%$ & $8 \%$ & & $9 \%$ & $7 \%$ \\
\hline St.D range deviation & & $11 \%$ & & $11 \%$ & $5 \%$ & $4 \%$ & $2 \%$ & $2 \%$ & & $5 \%$ & $1 \%$ \\
\hline 5 Percentile range deviation & & $11 \%$ & & $11 \%$ & $2 \%$ & $10 \%$ & $4 \%$ & $1 \%$ & & $0 \%$ & $2 \%$ \\
\hline 51 Percentile range deviation & & $17 \%$ & & $10 \%$ & $17 \%$ & $10 \%$ & $12 \%$ & $10 \%$ & & $9 \%$ & $10 \%$ \\
\hline 95 Percentile range deviation & & $19 \%$ & & $19 \%$ & $14 \%$ & $1 \%$ & $1 \%$ & $4 \%$ & & $13 \%$ & $2 \%$ \\
\hline
\end{tabular}

4 
1 Table S6. Correlation coefficients of the detected equifinalities. The first two digits after 2 decimal point are displayed. Values $<0.14$ are not shown.

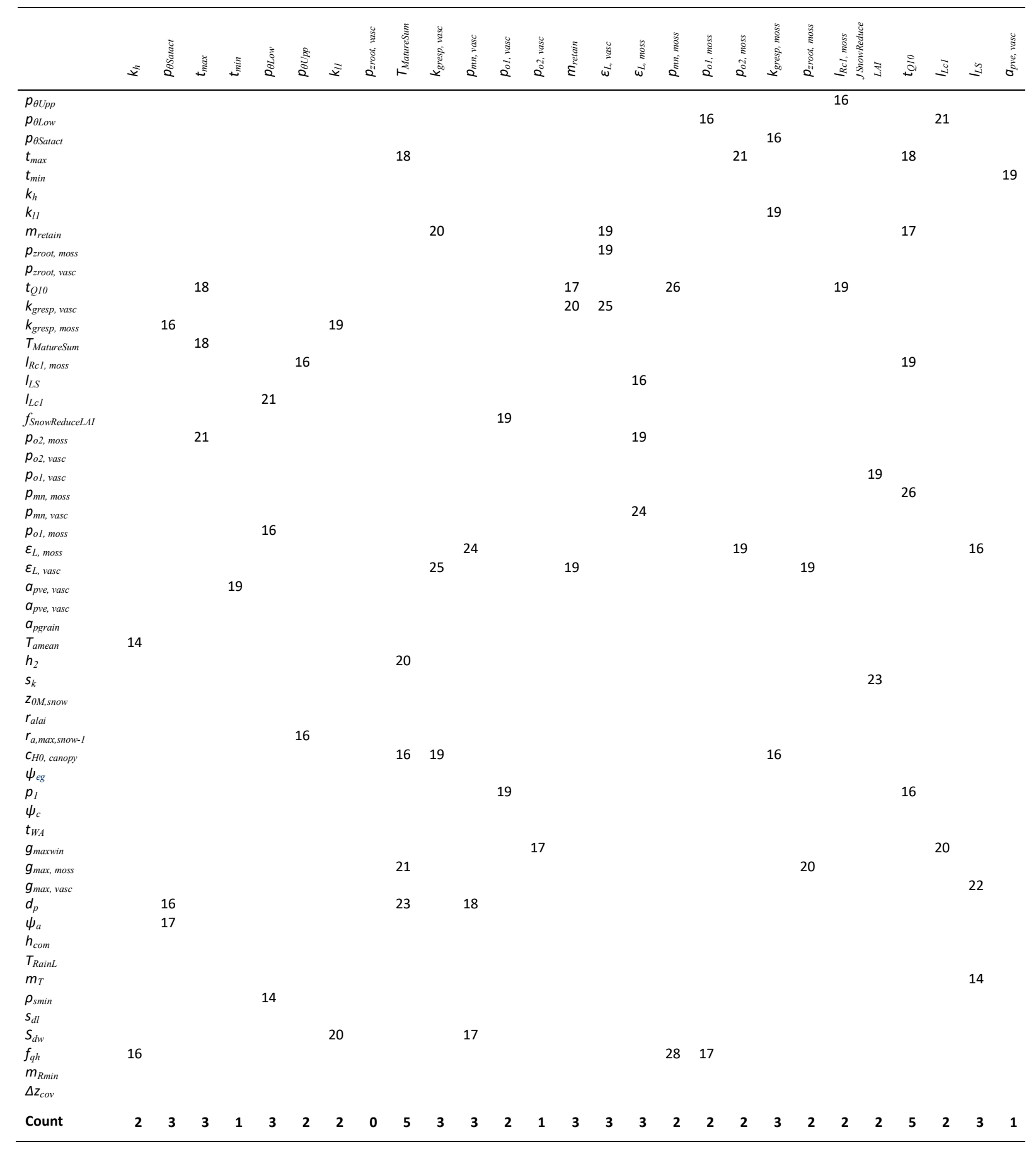
3

4 
1 Table S6 continued.

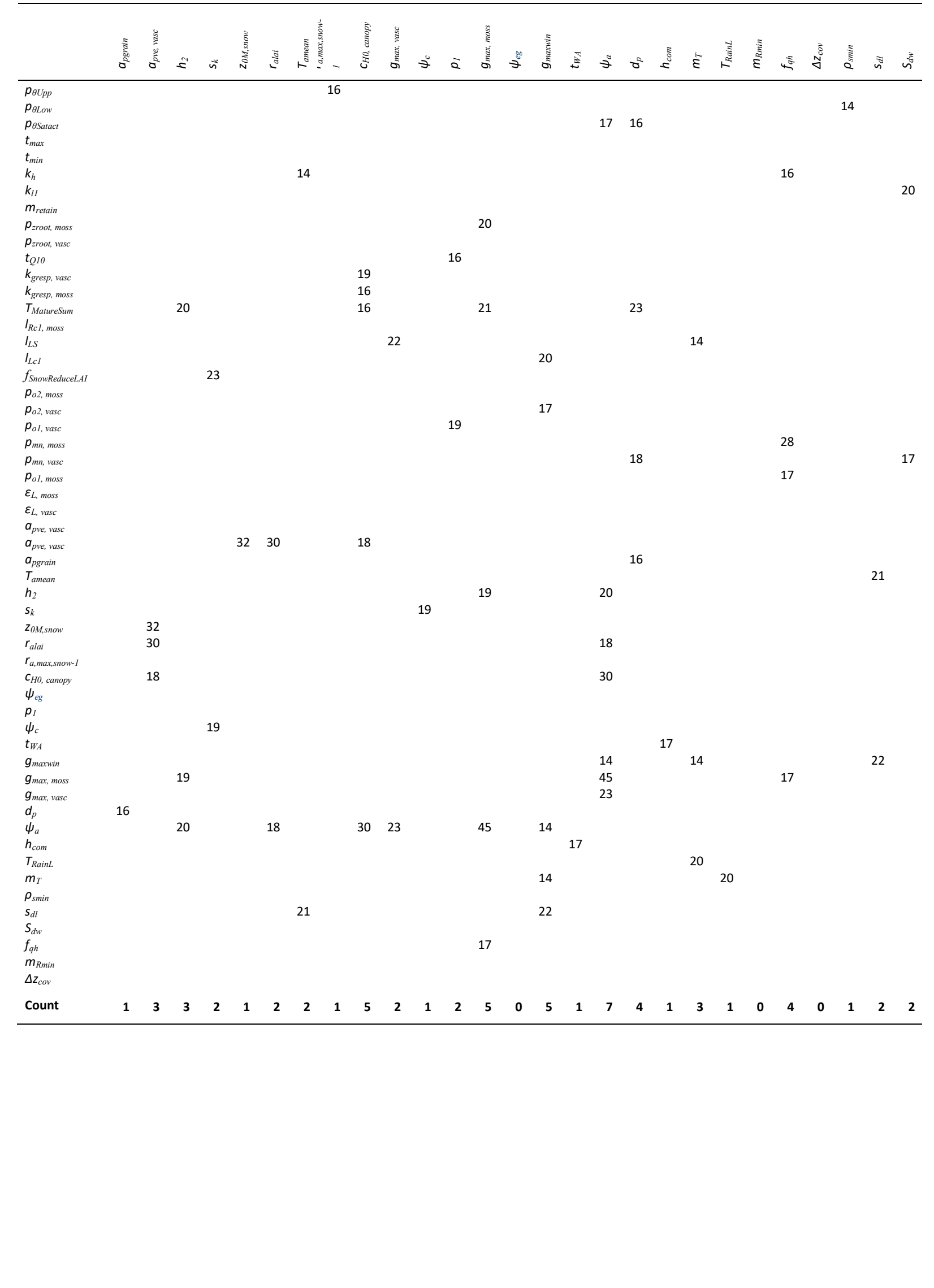




\section{Supplementary Figures}
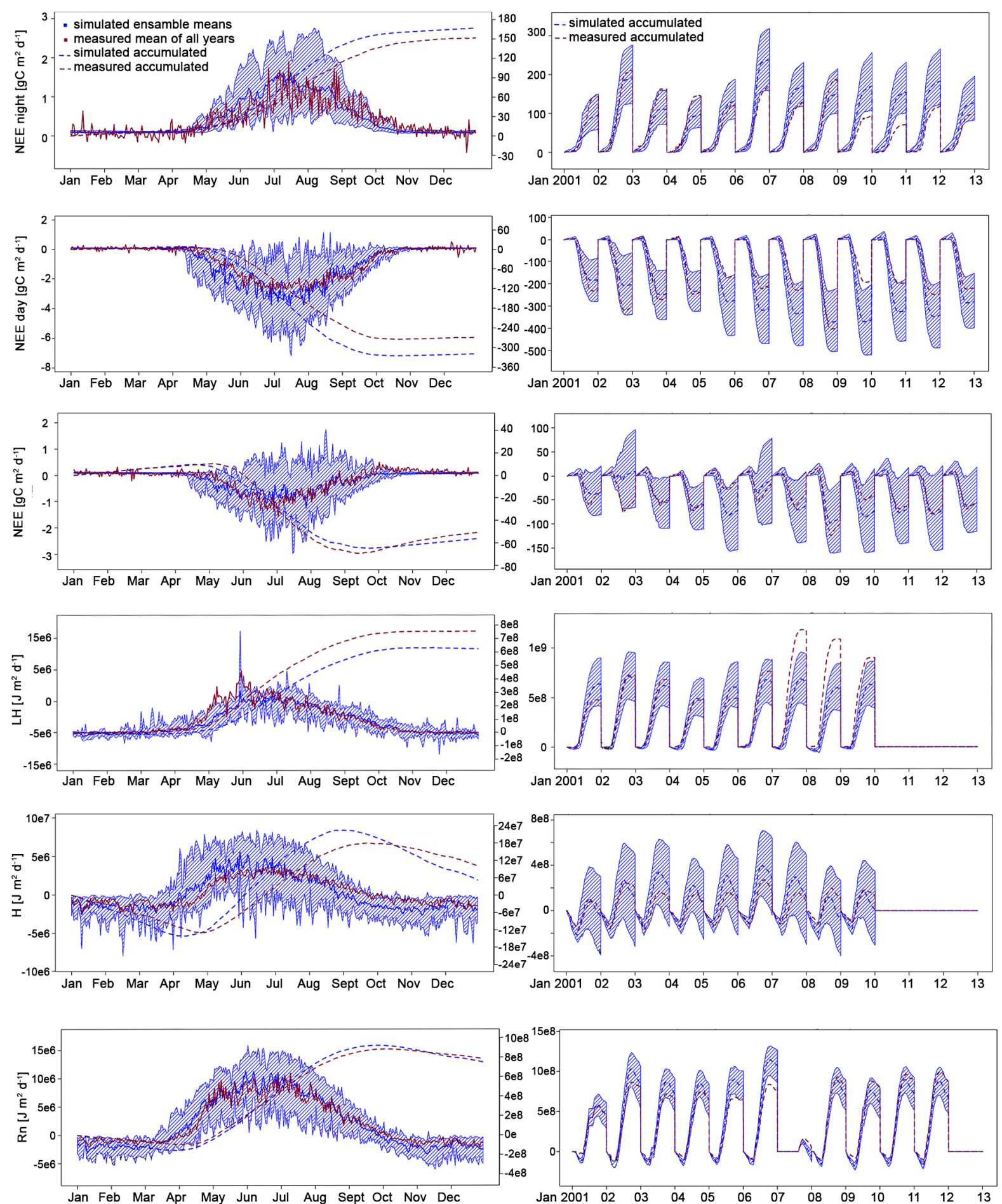

3 Figure S1. Model fit to observations. Left column: simulated and measured mean of all years.

4 Right column: cumulated values for each year. 

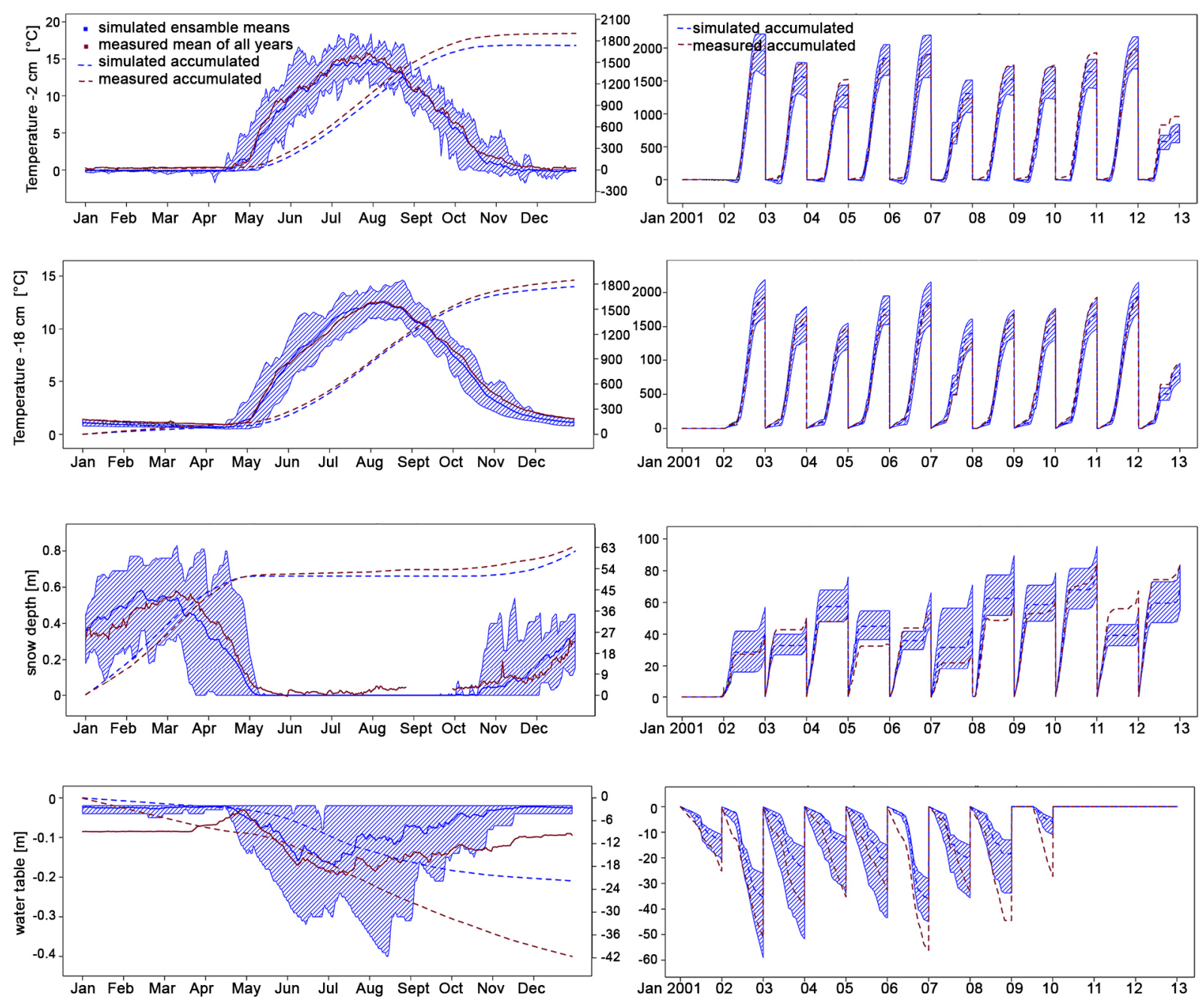

3 Figure S1 continued: Model fit to observations. Left column: simulated and measured mean 4 of all years. Right column: cumulated values for each year 


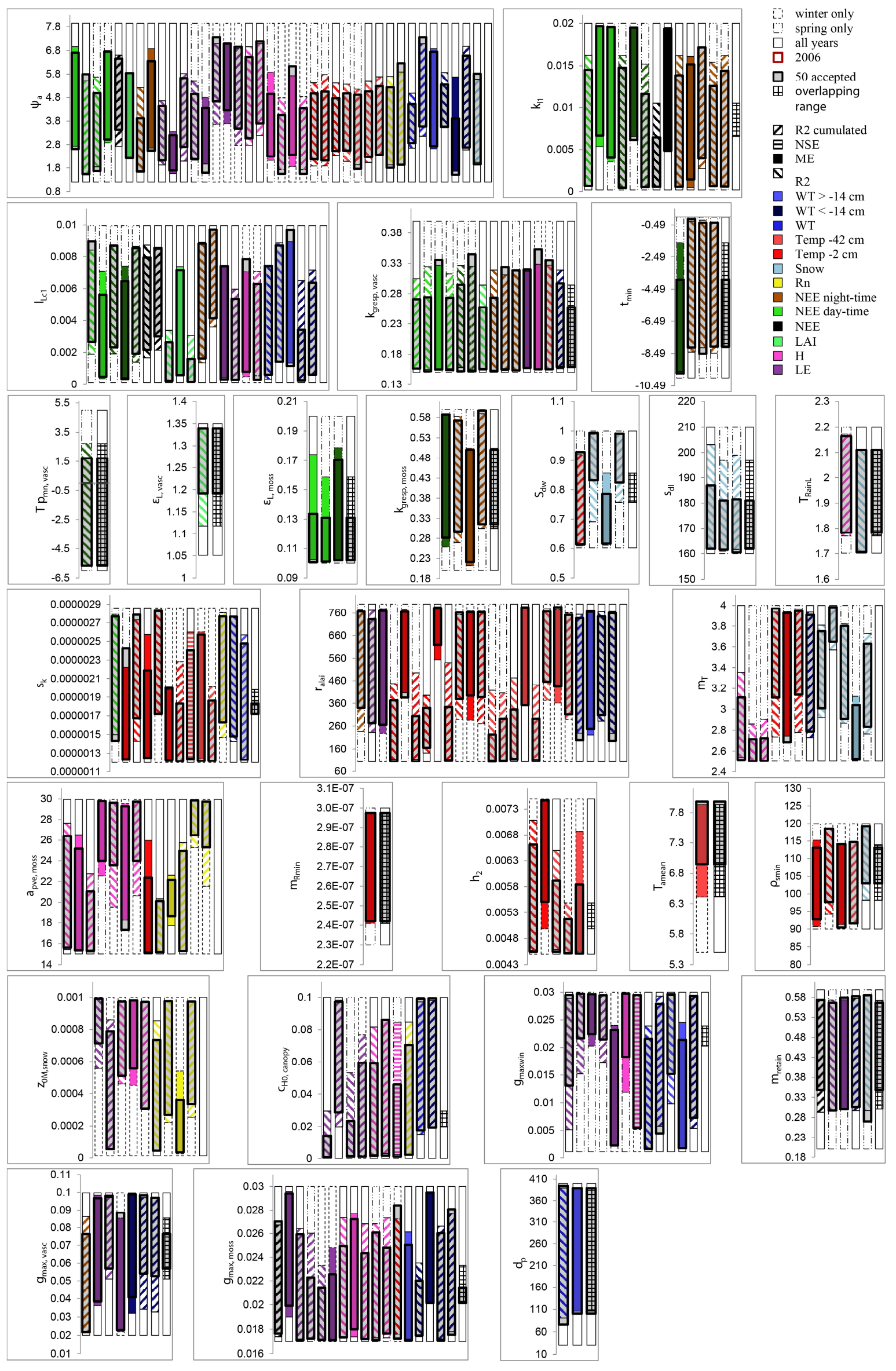

2 Figure S2. Accepted parameter ranges. The last bar in each bar chart shows the overlapping

3 range. If empty, ranges are not overlapping 
spring $\mathrm{R}^{2}$

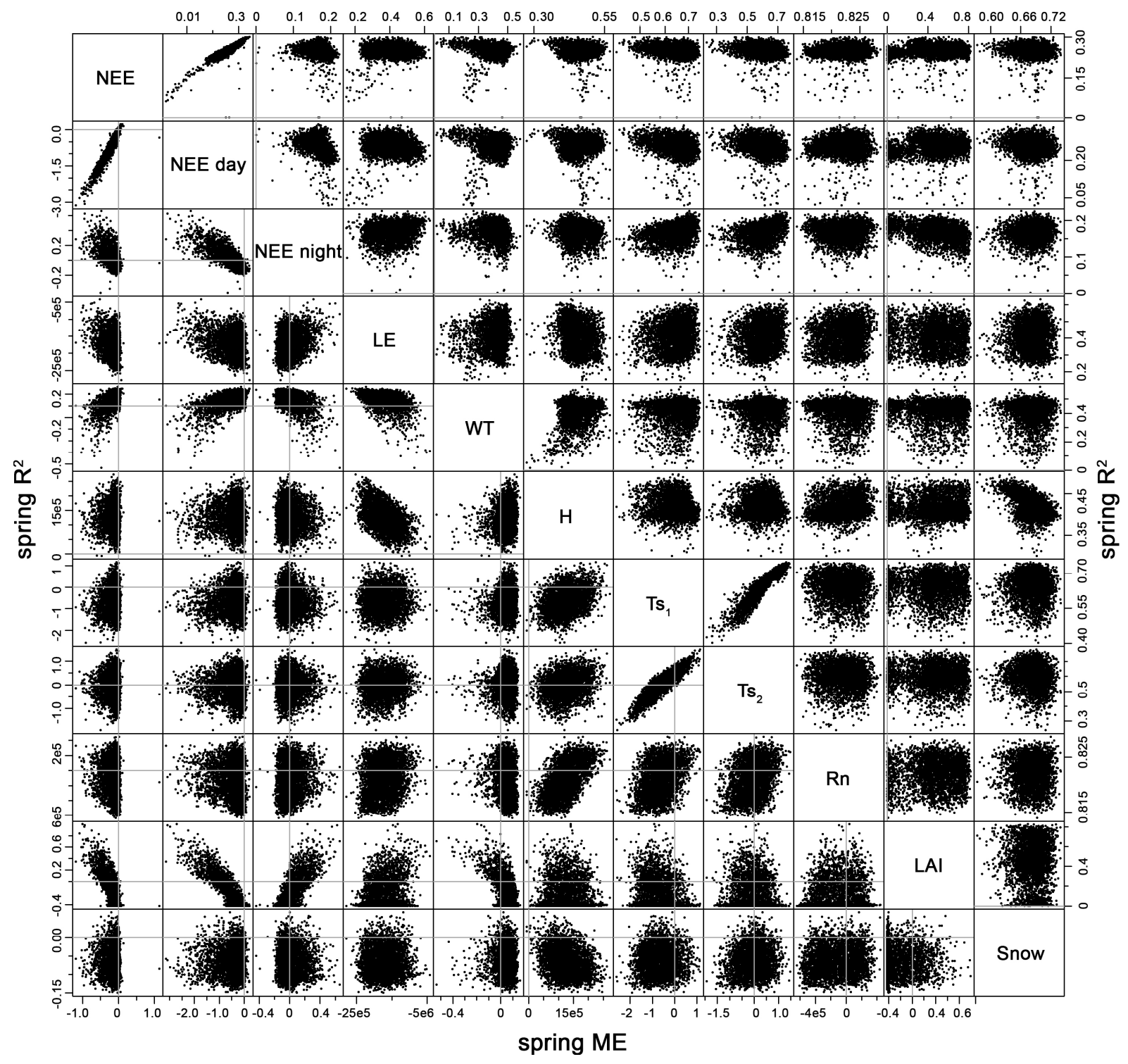

2 Figure S3. Correlations between performance indices in the prior distribution during spring

3 time only. Upper panel: R2, lower panel: ME. Each of the dots represents a parameter set.

4 Grey lines indicate the axes through zero. 


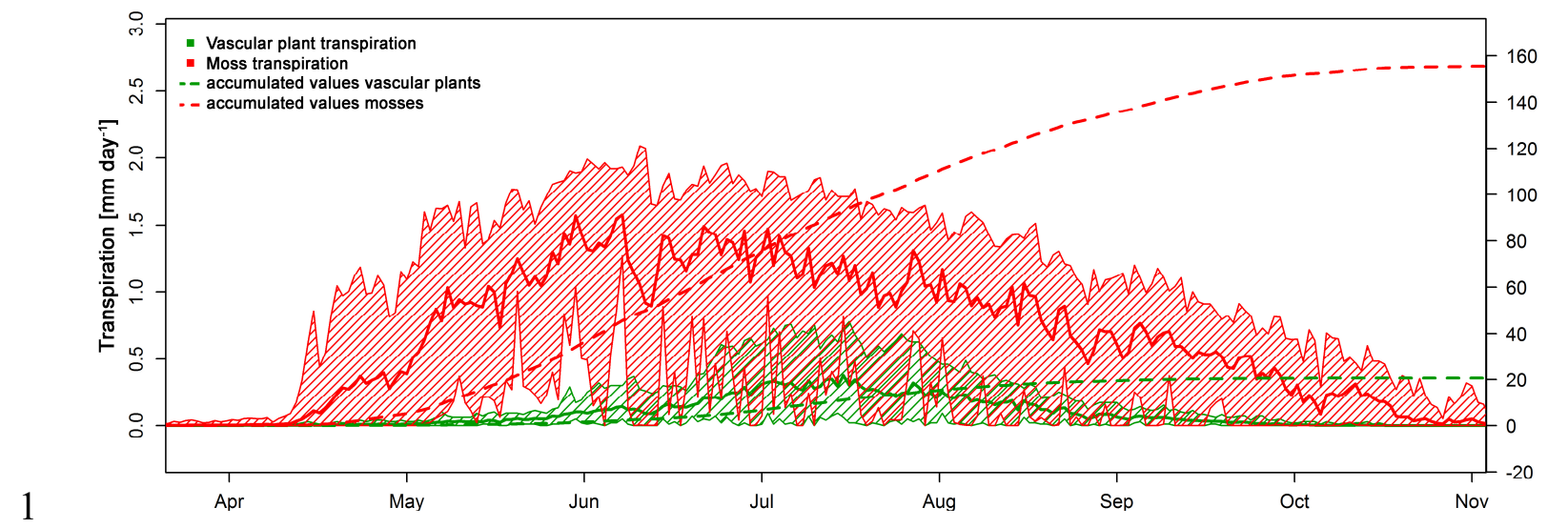

2 Figure S4. 12 year mean of transpiration from mosses and vascular plants. The hatched area 3 shows the range of the 51 runs with selected performance in NEE, the solid line its mean.

4

5

6 


\section{References}

Axelsson, B. and Ågren, G.: Tree growth model (PT 1) - a development paper. Swedish Coniferous Forest Project. Swedish University of Agricultural Sciences, Department of Ecology and Environmental Research, Uppsala. Sweden, Internal Report 41, 79pp, 1976.

Berglund, E. R. and Mace, A. C.: Seasonal Albedo Variation of Black Srpuce and SphagnumSedge Bog Cover Types, Journal of applied meteorology, 806-812, 1972.

Brooks, R. H. and Corey, A. T.: Hydraulic Properties of Porous Media, Hydrology Paper No. 3, Colorado State University, Fort Collins, Colorado, US, 27pp, 1964.

Clymo, R. S. and Hayward, P. M.: The Ecology of Sphagnum, in: Bryophyte Ecology, Smith, A. J. E. (Ed.), Springer Netherlands, 229-289, 1982.

Davidson, H. R. and Campbell, C. A.: The effect of temperature, moisture and nitrogen on the rate of development of spring wheat as measured by degree days, Canadian journal of plant science, 63, 833-846, 1983.

Fulkerson, W. J. and Donaghy, D. J.: Plant-soluble carbohydrate reserves and senescence-key criteria for developing an effective grazing management system for ryegrass-based pastures: A review, Animal Production Science, 41, 261-275, 2001.

Grace, J.: The Growth-Physiology of Moorland Plants in relation to their Aerial Environment. Ph.D. thesis, Univ. Sheffield, Sheffield, UK, 1973.

Granberg, G., Grip, H., Löfvenius, M. O., Sundh, I., Svensson, B. H., and Nilsson, M.: A simple model for simulation of water content, soil frost, and soil temperatures in boreal mixed mires, Water Resour. Res., 31, 3371-3382, doi:10.1029/1999WR900216, 1999.

Jansson, P.-E., Karlberg, L.: Coupled heat and mass transfer model for soil-plant-atmosphere systems. Royal Institute of Technology, Stockholm, 484 pp., accessed: 17 November 2015 https://drive.google.com/file/d/0B0-WJKp0fmYCZ0JVeVgzRWFIbUk/view?pli=1, 2010.

Kellner, E.: Surface energy fluxes and control of evapotranspiration from a Swedish Sphagnum mire, Agricultural and Forest Meteorology, 110, 101-123, doi:10.1016/S01681923(01)00283-0, 2001.

Kellner, E. and Lundin, L.-C.: Calibration of time domain reflectometry for water content in peat soil, Nordic Hydrology, 32, 315-332, 2001.

Kondratiev, K. Y., Mironova, Z. F., and Otto, A. N.: Spectral albedo of natural surfaces, pure and applied geophysics, 59, 207-216, 1964.

Körner, C.: Alpine plant life: Functional plant ecology of high mountain ecosystems, Springer, Berlin, New York, 338pp, 1999.

Kummerow, J. and Ellis, B. A.: Temperature effect on biomass production and root/shoot biomass ratios in two arctic sedges under controlled environmental conditions, Bot., 62, 2150-2153, doi:10.1139/b84-294, 1984.

Metzger, C., Jansson, P.-E., Lohila, A., Aurela, M., Eickenscheidt, T., Belelli-Marchesini, L., Dinsmore, K. J., Drewer, J., van Huissteden, J., and Drösler, M.: $\mathrm{CO}_{2}$ fluxes and ecosystem dynamics at five European treeless peatlands - merging data and process oriented modeling, Biogeosciences, 12, 125-146, doi:10.5194/bg-12-125-2015, 2015.

Päivänen, J.: Hydraulic conductivity and water retention in peat soils, Acta Forestalia Fennica, 129, 1973.

Petzold, D. E. and Rencz, A. N.: The albedo of selected subarctic surfaces, Arctic and Alpine Research, 393-398, 1975.

Ratkowsky, D. A., Olley, J., McMeekin, T. A., and Ball, A.: Relationship between temperature and growth rate of bacterial cultures, Journal of Bacteriology, 149, 1-5, 1982.

Rice, S. K., Aclander, L., and Hanson, D. T.: Do bryophyte shoot systems function like vascular plant leaves or canopies?: Functional trait relationships in Sphagnum mosses (Sphagnaceae): Functional trait relationships in Sphagnum mosses (Sphagnaceae), American journal of botany, 95, 1326-1330, doi:10.3332/ajb.0800019, 2008. 
1 Shaw R.H. and Pereira, A.R.: Aerodynamic roughness of a plant canopy: a numerical experiment. Agricultural Forest Meteorology, 26: 51-65, 1982.

3 Thomas, H. and Stoddart, J. L.: Leaf Senescence, Ann. Rev. Plant Physiol., 31, 83-111, 1980.

4 van de Weg, M. J., Fetcher, N., and Shaver, G.: Response of dark respiration to temperature in Eriophorum vaginatum from a 30-year-old transplant experiment in Alaska, Plant Ecology \& Diversity, 6, 337-301, doi:10.1080/17560874.2012.729628, 2013.

Vermeij, I.: Relating phenology to the gross primary production in a boreal peatland, using the greenness index, MSc thesis Biology, Wageningen University, Wageningen, 2013.

White, L. M.: Carbohydrate Reserves of Grasses: A Review, Journal of Range Management, 26, 13-18, 1973.

Wingler, A.: The role of sugars in integrating environmental signals during the regulation of leaf senescence, Journal of Experimental Botany, 57, 391-399, doi:10.1093/jxb/eri279, 2005.

Wohlfahrt, G., Bahn, M., Haubner, E., Horak, I., Michaeler, W., Rottmar, K., Tappeiner, U., and Cernusca, A.: Inter-specific variation of the biochemical limitation to photosynthesis and related leaf traits of 30 species from mountain grassland ecosystems under different land use, Plant, Cell and Environment, 22, 1281-1296, 1999.

Zhao, W., Hidenori, T., and Zhao, H.: Estimation of vegetative surface albedo in the Kushiro Mire with Landsat TM data, Chin. Geograph.Sc., 7, 278-288, doi:10.1007/s11769-997-

$20 \quad 0056-4,1997$. 